\title{
Synthesis, characterisation and structural studies of amidinate and guanidinate alkaline earth-transition metal bonded complexes
}

\author{
Ross Green, Alicia C. Walker, Matthew P. Blake* and Philip Mountford* \\ Chemistry Research Laboratory, Department of Chemistry, University of Oxford, Mansfield Road, Oxford \\ OX1 3TA, UK. \\ E-mail: philip.mountford@chem.ox.ac.uk and matthew.blake@chem.ox.ac.uk
}

\begin{abstract}
Reaction of magnesium amidinate complexes of the form $\left[\left\{\mathrm{MesC}(\mathrm{NR})_{2}\right\} \mathrm{MgBr}\left(\mathrm{OEt}_{2}\right)\right]_{2}\left(\mathrm{R}={ }^{\mathrm{i}} \mathrm{Pr}\right.$, Dipp, Mes) with the potassium salts of transition metal anions $\mathrm{K}\left[\mathrm{CpFe}(\mathrm{CO})_{2}\right](\mathrm{K}[\mathrm{Fp}])$ and $\mathrm{K}\left[\mathrm{Co}(\mathrm{CO})_{3}\left(\mathrm{PCy}_{3}\right)\right](\mathrm{THF})_{2}$ gave the complexes $\left\{\mathrm{MesC}(\mathrm{NR})_{2}\right\} \mathrm{MgFp}(\mathrm{THF})$ and $\left\{\mathrm{MesC}(\mathrm{NR})_{2}\right\} \mathrm{Mg}\left\{\mathrm{Co}(\mathrm{CO})_{3}\left(\mathrm{PCy}_{3}\right)\right\}(\mathrm{THF})$. Single crystal X-ray diffraction studies of $\left\{\mathrm{MesC}(\mathrm{NR})_{2}\right\} \mathrm{Mg}\left\{\mathrm{Co}(\mathrm{CO})_{3}\left(\mathrm{PCy}_{3}\right)\right\}(\mathrm{THF})$ for $\mathrm{R}={ }^{\mathrm{i}} \mathrm{Pr}$ and Dipp confirm these to have $\mathrm{Mg}-\mathrm{Co}$ bonds in the solid state. Reaction of the structurally similar magnesium guanidinate complex $\left\{\mathrm{Me}_{2} \mathrm{NC}(\mathrm{NDipp})_{2}\right\} \mathrm{MgI}\left(\mathrm{OEt}_{2}\right)$ with the aforementioned transition metal anions and additional $\mathrm{K}\left[\mathrm{Co}(\mathrm{CO})_{3}\left(\mathrm{PPh}_{3}\right)\right](\mathrm{THF})$ gave the series of complexes $\left[\left\{\mathrm{Me}_{2} \mathrm{NC}(\mathrm{NDipp})_{2}\right\} \mathrm{MgFp}\right]_{2}$, $\left\{\mathrm{Me}_{2} \mathrm{NC}(\mathrm{NDipp})_{2}\right\} \mathrm{Mg}\left\{\mathrm{Co}(\mathrm{CO})_{3}\left(\mathrm{PCy}_{3}\right)\right\}\left(\mathrm{OEt}_{2}\right)$ and $\left\{\mathrm{Me}_{2} \mathrm{NC}(\mathrm{NDipp})_{2}\right\} \mathrm{Mg}\left\{\mathrm{Co}(\mathrm{CO})_{3}\left(\mathrm{PPh}_{3}\right)\right\}\left(\mathrm{OEt}_{2}\right)$. Structural authentication by X-ray crystallography showed $\left[\left\{\mathrm{Me}_{2} \mathrm{NC}(\mathrm{NDipp})_{2}\right\} \mathrm{MgFp}\right]_{2}$ to be a very rare example of a base-free alkaline earth-transition bonded complex, having two Mg-Fe bonds. IR and diffusion NMR spectroscopy were carried out to gain further insight into the solid state and solution phase structures.
\end{abstract}

\section{Graphical abstract}

The first amidinate and guanidinate magnesium complexes with bonds to transition metals have been synthesised and structurally authenticated. IR and diffusion NMR spectroscopy provide further evidence for their structural forms in the solid state and solution. 

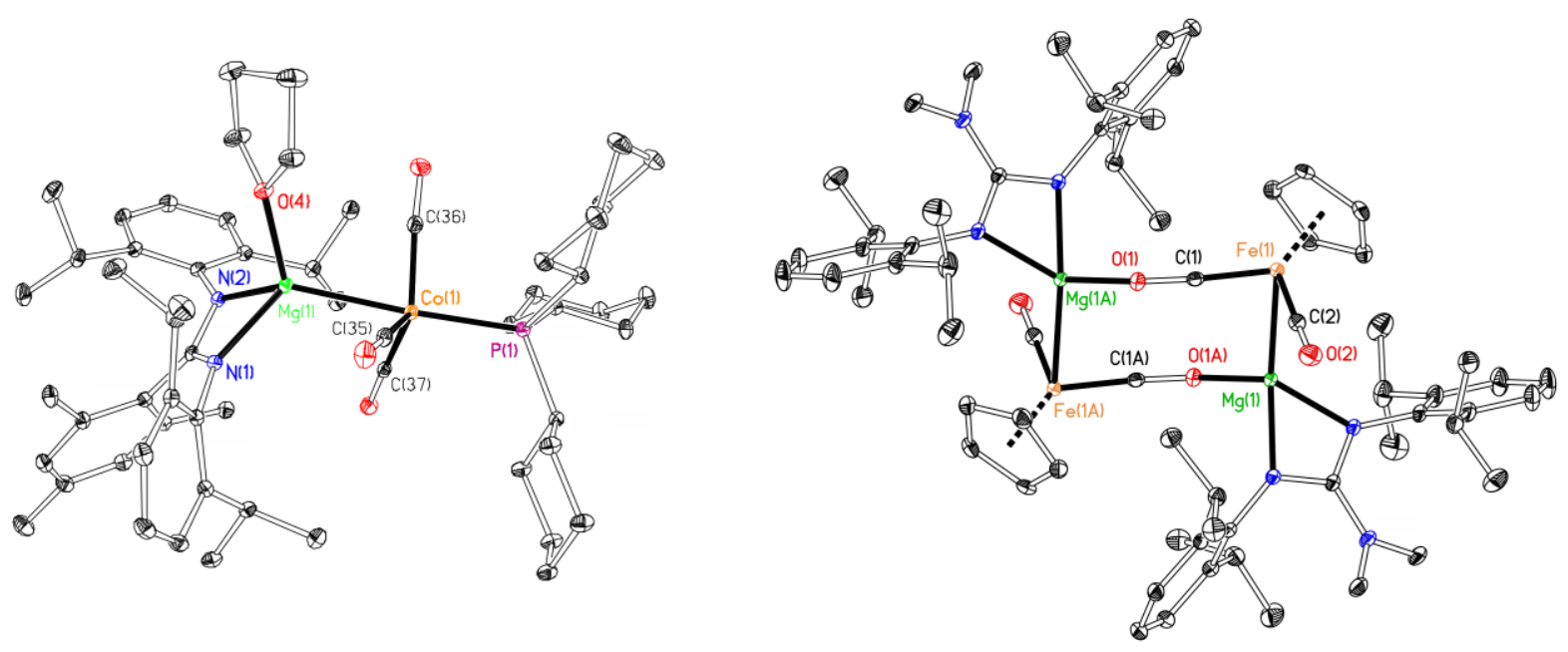

\section{Keywords}

Metal- metal bonding; Alkaline earth; Transition metal; Magnesium; Amidinate; Guanidinate.

\section{Introduction}

Compounds containing metal- metal bonds have been the focus of renewed attention for over a decade.[1] Reports of $\mathrm{Zn}-\mathrm{Zn}$ [2] and $\mathrm{Mg}-\mathrm{Mg}$ [3] single bonds, transition metal quintuple bonds, [4] Group 12 homo- and hetero-trimetallic[5] species and myriad $4 f$ element- and $5 f$ element- main group and transition metal bonded complexes[6] have piqued interest in the synthesis, structure, bonding and reactivity of such compounds. One area that has received little attention until very recently is that of Ae-TM (alkaline earth-transition metal) bonding. Since the first report of $\mathrm{Cp}(\mathrm{DPPE}) \mathrm{FeMgBr}(\mathrm{THF})_{2}$ (1)[7] by Felkin in 1974 there have been few examples of structurally authenticated Ae- TM bonded complexes, most of which feature Ae $=\mathrm{Mg}$. These include Green's $\mathrm{Mg}-$ Mo species $\mathrm{Cp}_{2} \mathrm{Mo}(\mathrm{H})\left\{\mathrm{MgBr}(\mathrm{THF})_{2}\right\},[8]$ the $\mathrm{Mg}-\mathrm{Ir}$ species $\left[\mathrm{Cp} * \operatorname{Ir}\left(\mathrm{PMe}_{3}\right)(\mathrm{H}) \mathrm{MgPh}\right]_{2},[9]$ and the two $\mathrm{Mg}-\mathrm{Co}$ species $\mathrm{CpCo}\left(\eta^{3}-\mathrm{C}_{3} \mathrm{H}_{5}\right) \mathrm{MgBr}(\mathrm{THF})_{2}$ (2) and $\mathrm{CpCo}\left(\eta^{2}-\mathrm{C}_{2} \mathrm{H}_{4}\right)(\mathrm{Ph}) \mathrm{MgBr}(\mathrm{TMEDA})$ (3).[10] The first $\mathrm{Be}-\mathrm{TM}$ bonded compounds, $\left(\mathrm{Cy}_{3} \mathrm{P}\right)_{2} \mathrm{Pt}\{\mathrm{Be}(\mathrm{Cl}) \mathrm{X}\}(\mathrm{X}=\mathrm{Cl}$ or $\mathrm{Me})$, were only characterised and structurally authenticated as recently as 2009.[11] $\mathrm{Ca}-\mathrm{TM}$ bonds are even more elusive; $\left[\mathrm{CaFp}_{2}(\mathrm{THF})_{3}\right]_{2}(\mathbf{4})[12]$ and $\left[\mathrm{Ca}\left\{\mathrm{Co}(\mathrm{CO})_{3}\left(\mathrm{PCy}_{3}\right\}_{2}(\mathrm{THF})_{3}\right]_{\mathrm{x}}(\mathbf{5})[13]\right.$ remain the only examples reported to date.

Group 2 contains some of the most electropositive elements and as a consequence Ae- TM bonds are considerably ionic. Any potential TM bond partner must therefore be able to accommodate significant anionic charge. Investigation of the literature[14] for similarly polar M- TM bonded species (e.g. where $M=$ lanthanide $(\operatorname{Ln})$ or actinide $(A n))[15]$ or early-late heterobimetallics[16] reveals only a handful of metal anions that are routinely exploited for these purposes. These "privileged anions" are $\left[\mathrm{CpM}(\mathrm{CO})_{2}\right]^{-}\left(\mathrm{M}=\mathrm{Fe}\right.$ ("Fp") or $\mathrm{Ru}\left(\right.$ ("Rp")), $\left[\mathrm{Cp}_{2} \mathrm{Re}\right]^{-},\left[\mathrm{Co}(\mathrm{CO})_{4}\right]^{-}$and its monophosphine analogue 
$\left[\mathrm{Co}(\mathrm{CO})_{3}\left(\mathrm{PR}_{3}\right)\right]^{-}$. Shore et al. have also utilised the "supernucleophile" $\left[\mathrm{Fe}(\mathrm{CO})_{4}\right]^{2-}$ successfully to form $\mathrm{Yb}-\mathrm{Fe}$ bonded structures.[17] However attempts to extend this to achieve Ae- TM bonds were unsuccessful.[13] Carbonylate anions stabilise the build-up of negative charge on the TM moiety through $\pi$ back-donation from $\operatorname{TM}\left(\mathrm{d}_{\pi}\right)$ to $\mathrm{C}-\mathrm{O}\left(\pi^{*}\right)$ orbitals. However, their presence introduces the possibility of Ae- $(\mu-\mathrm{OC})-\mathrm{TM}$ isocarbonyl bonding, which can often occur in preference to Ae- TM bonding. This dilemma has been referred to by Kempe as "the isocarbonyl problem"[15] and has been similarly observed by Marks for the highly oxophilic $5 f$ elements in the pursuit of An-TM bonds.[18]

Work in our laboratories has recently led to the report of several structurally authenticated Ae- TM bonded species, including $\left[\mathrm{MgFp}_{2}(\mathrm{THF})\right]_{2}(\mathbf{6})[12]$ and $\left[\mathrm{Mg}\left\{\mathrm{Co}(\mathrm{CO})_{3}\left(\mathrm{PCy}_{3}\right)\right\}_{2}(\mathrm{THF})\right]_{2}(7),[13]$ synthesised from the reductive cleavage of $\mathrm{Fp}_{2}$ and $\left[\mathrm{Co}(\mathrm{CO})_{3}\left(\mathrm{PCy}_{3}\right)\right]_{2}$ by a $\mathrm{Mg} / \mathrm{Hg}$ amalgam. These were found to undergo significant structural changes in solution, with loss of the $\mathrm{Mg}-\mathrm{Fe}$ interaction for the latter. This gave us significant impetus to synthesise $\left({ }^{\mathrm{Dipp}} \mathrm{NacNac}\right) \mathrm{MgFp}$ (THF) (8, Dipp = 2,6diisopropylphenyl, $\left.{ }^{\mathrm{R}} \mathrm{NacNac}=\mathrm{HC}\{\mathrm{C}(\mathrm{Me}) \mathrm{NR}\}_{2}\right)$, isolated from the salt-elimination reaction of ( $\left.{ }^{\text {Dipp }} \mathrm{NacNac}\right) \mathrm{MgI}(\mathrm{THF})$ and K[Fp].[19] Complex 8 is soluble in non-donor solvents and contains a $\mathrm{Mg}-\mathrm{Fe}$ bond in both the solid state and solution. Complex $\mathbf{8}$ features a $\beta$-diketiminate (NacNac) ligand, ubiquitous in Ae chemistry for having stabilising and solubilising properties.[20] Tuning of these properties can be accomplished through variation of substituents on the $\mathrm{N}$-atoms. A complex featuring a larger Ae for instance, may be kinetically stabilised via increased steric protection from bulky N-aryl groups.

Amidinates $\left(\mathrm{R}^{\prime} \mathrm{C}(\mathrm{NR})_{2}\right)$ and guanidinates $\left(\mathrm{R}_{2}^{\prime} \mathrm{NC}(\mathrm{NR})_{2}\right)$ are similar classes of bidentate mono-anionic ligand that have been successfully deployed in Ae chemistry.[21] However, they are yet to be successfully exploited for Ae-TM bonding. As with $\beta$-diketiminates, these ligands can be readily modified at their $\mathrm{N}$-substituents to allow the properties of the complex to be tuned as required. Amidinates and guanidinates differ from $\beta$-diketiminates in having only one, rather than three, backbone carbons. This results in formation of a four-membered, rather than six-membered ring, when complexed to the metal and a more acute $\mathrm{N}-\mathrm{Ae}-\mathrm{N}$ bite-angle (typically between 63 $\left.65^{\circ}[21 \mathrm{a}]\right)$, giving a potentially more accessible metal centre to participate in metal-metal bonding with a suitable anion. We were therefore interested to see if our initial success with $\mathbf{8}$ could be extended to complexes with amidinate and guanidinate supporting ligands with a view to increasing the breadth of Ae- TM bonded systems, particularly those where metal-metal bonding is maintained in solution.

\section{Results and discussion}

\subsection{Magnesium amidinate complexes}

$\left[\left\{\mathrm{MesC}\left(\mathrm{N}^{\mathrm{i}} \mathrm{Pr}\right)_{2}\right\} \mathrm{Mg}(\mu-\mathrm{Br})\left(\mathrm{OEt}_{2}\right)\right]_{2}(\mathbf{9})$ was prepared in $88 \%$ yield from ${ }^{\mathrm{i}} \mathrm{PrNCN}{ }^{\mathrm{i}} \mathrm{Pr}$ and $\mathrm{MesMgBr}$ in 
$\mathrm{Et}_{2} \mathrm{O}$ using an analogous procedure to that reported by Coles et al.[21c] Diffraction quality crystals of 9 were grown from an $\mathrm{Et}_{2} \mathrm{O}$ solution at $5{ }^{\circ} \mathrm{C}$. The structure is shown in Fig. 1. Complex 9 is dimeric in the sold state with two $\mu$-Br bridging the $\mathrm{Mg}$ centres. Each $\mathrm{Mg}$ centre is five-coordinate with distorted trigonal bipyramidal geometry. Distances and angles are as expected and similar to that for reported by Coles for the analogous $\left[\left\{\mathrm{MesC}(\mathrm{NCy})_{2}\right\} \mathrm{Mg}(\mu-\mathrm{Br})\left(\mathrm{OEt}_{2}\right)\right]_{2}(\mathbf{1 0})$. In particular the bite angle of the amidinate in $9\left(\mathrm{~N}(1)-\mathrm{Mg}(1)-\mathrm{N}(2)=64.29(6)^{\circ}\right)$ is comparable to that for $\mathbf{1 0}\left(64.76(8)^{\circ}\right)$.

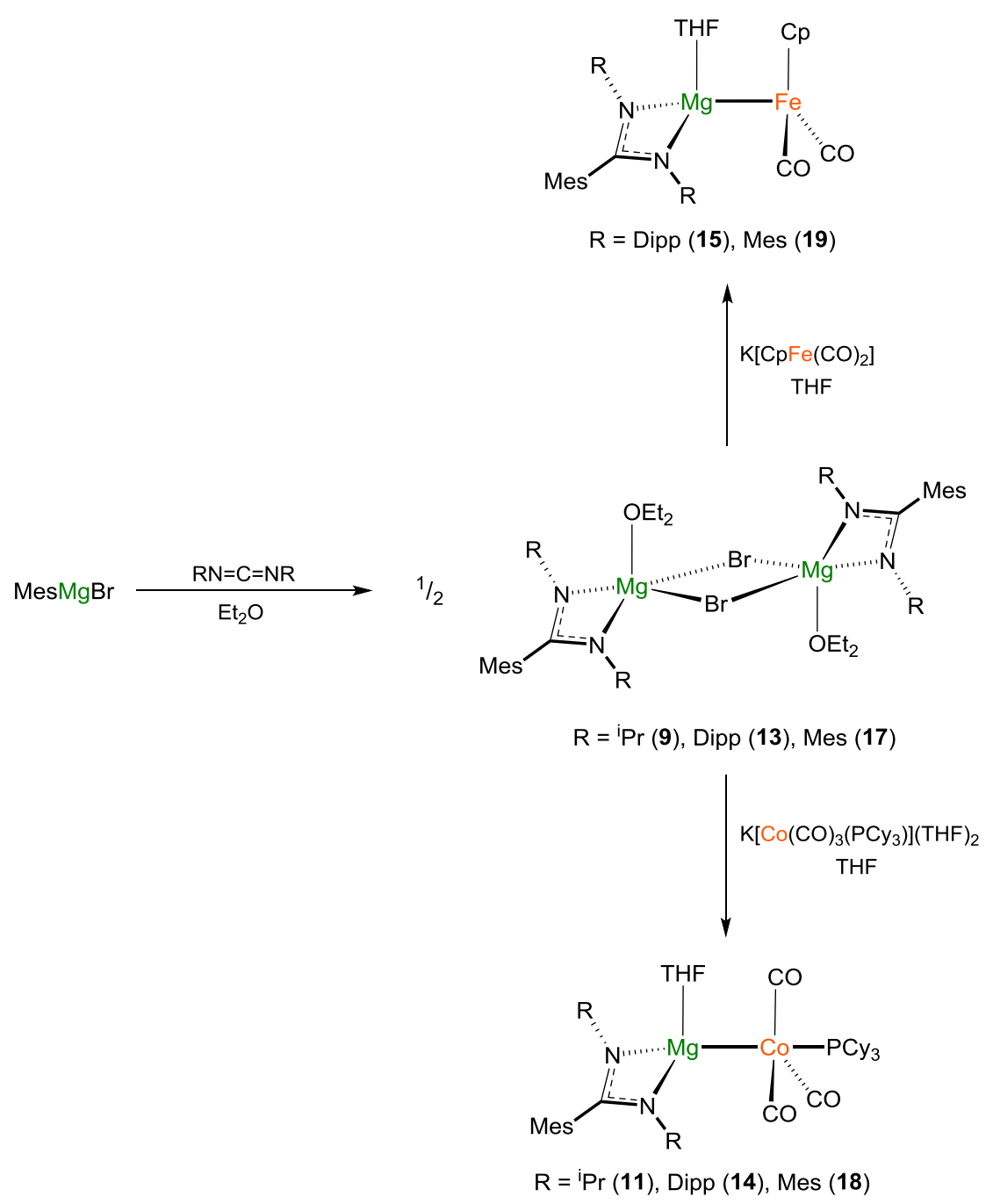

Scheme 1. Synthetic routes to $\operatorname{Mg}-\mathrm{Fe}(\mathbf{1 5}, \mathbf{1 9})$ and $\operatorname{Mg}-\mathrm{Co}(\mathbf{1 1}, \mathbf{1 4}, \mathbf{1 8})$ bonded amidinate complexes. 


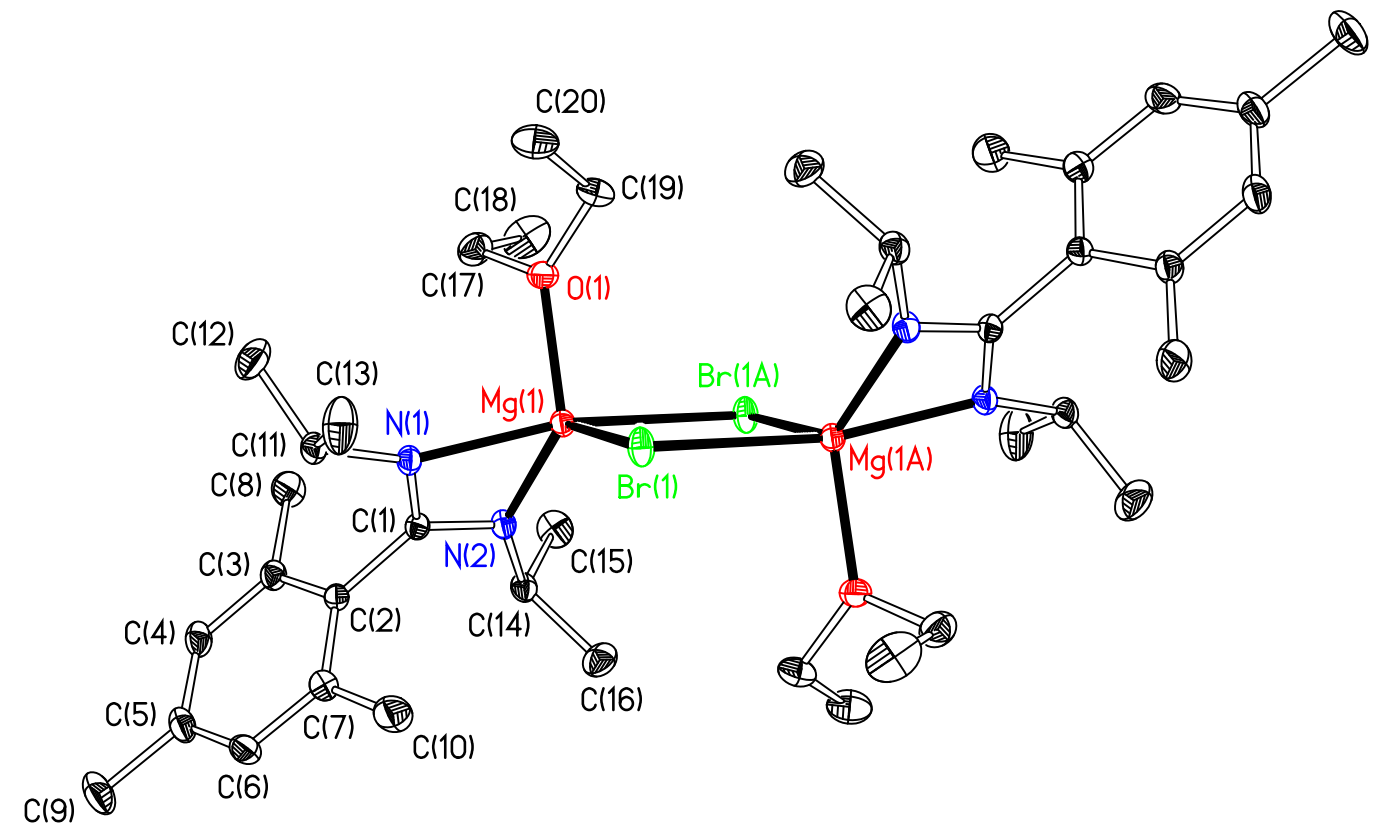

Figure 1. Displacement ellipsoid plot (20\% probability) of $\left[\left\{\mathrm{MesC}\left(\mathrm{N}^{\mathrm{i}} \mathrm{Pr}\right)_{2}\right\} \mathrm{Mg}(\mu-\mathrm{Br})\left(\mathrm{OEt}_{2}\right)\right]_{2}(\mathbf{9})$. $\mathrm{H}$ atoms omitted. Atoms carrying the suffix ' $A$ ' are related to their counterparts by the symmetry operator 1-x, 1-y, 1-z. Selected distances $(\AA)$ and angles $\left(^{\circ}\right): \operatorname{Mg}(1)-\operatorname{Br}(1) 2.6677(8), \operatorname{Mg}(1)-\operatorname{Br}(1 \mathrm{~A})$ 2.5560(8), $\quad \operatorname{Mg}(1)-\mathrm{N}(1) \quad 2.1144(17), \quad \operatorname{Mg}(1)-\mathrm{N}(2) \quad 2.0757(17), \quad \mathrm{Mg}(1)-\mathrm{O}(1) \quad 2.0398(16)$, $\mathrm{N}(1)-\mathrm{Mg}(1)-\mathrm{N}(2) \quad 64.29(6), \quad \mathrm{N}(1)-\mathrm{Mg}(1)-\mathrm{Br}(1) \quad 164.69(5), \quad \mathrm{N}(1)-\mathrm{Mg}(1)-\operatorname{Br}(1 \mathrm{~A}) \quad 101.55(6)$, $\mathrm{N}(1)-\mathrm{Mg}(1)-\mathrm{O}(1)$ 97.40(7), N(1)- C(1)- N(2) 114.02(17), $\mathrm{Br}(1)-\mathrm{Mg}(1)-\mathrm{Br}(1 \mathrm{~A})$ 87.36(3).

The salt-elimination reaction of 9 with $\mathrm{K}\left[\mathrm{Co}(\mathrm{CO})_{3}\left(\mathrm{PCy}_{3}\right)\right](\mathrm{THF})_{2}$ in $\mathrm{THF}$ gave $\left\{\mathrm{MesC}\left(\mathrm{N}^{\mathrm{i}} \mathrm{Pr}\right)_{2}\right\} \operatorname{Mg}\left\{\mathrm{Co}(\mathrm{CO})_{3}\left(\mathrm{PCy}_{3}\right)\right\}(\mathrm{THF})(\mathbf{1 1})$ in $58 \%$ isolated yield as illustrated in Scheme 1. Diffraction quality crystals of $\mathbf{1 1}$ were grown from pentane at room temperature. The structure is shown in Fig. 2 and selected distances and angles in Table 1. The heterobimetallic species is monomeric in the solid state. The geometry at the four-coordinate $\mathrm{Mg}$ centre is approximately tetrahedral with two bonds to the bidentate amidinate ligand and one to each of the THF and $\mathrm{Co}(\mathrm{CO})_{3}\left(\mathrm{PCy}_{3}\right)$ groups. The $\mathrm{Mg}-\mathrm{Co}$ distance $(2.5310(7) \AA)$ is comparable with our previously reported 7 (endo $\mathrm{Mg}$ - Co 2.6163(6) and exo $\mathrm{Mg}-\mathrm{Co} 2.5427(6) \AA$ )[13] and Jonas' complexes 2

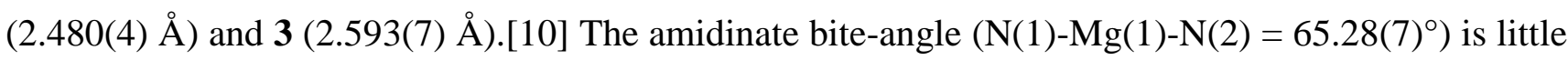
changed from 9.

The geometry at the five-coordinate Co centre is approximately trigonal bipyramidal with the three carbonyl groups lying in the equatorial plane and the $\mathrm{Mg}$ and $\mathrm{P}$ atoms occupying the axial positions with a near-linear arrangement $\left(\mathrm{Mg}-\mathrm{Co}-\mathrm{P}=174.58(2)^{\circ}\right)$. Interaction of the $\left[\mathrm{Co}(\mathrm{CO})_{3}\left(\mathrm{PR}_{3}\right)\right]^{-}$anion with a cationic acceptor is known to bring about a significant geometric change in the anion.[22] The sum of the three $\mathrm{P}-\mathrm{Co}-\mathrm{CO}$ angles $\left(\sum(\mathrm{P}-\mathrm{Co}-\mathrm{CO})\right)$ represents one measure of this geometric change and a way in which the strength of interaction can be quantified. A greater strength of interaction is expected to cause a deviation in this value away from that of the tetrahedral free anion towards that of 
trigonal bipyramidal geometry. In the case of $11 \sum(\mathrm{P}-\mathrm{Co}-\mathrm{CO})=302.27(12)^{\circ}$ consistent with a significant interaction between the $\mathrm{Mg}$ and Co centres and very similar to that measured for our recently reported $\mathrm{Mg}-\mathrm{Co}$ bonded 7 (300.9(2) and 303.2(2) $\left.{ }^{\circ}\right)$ and $\mathrm{Ca}-\mathrm{Co}$ bonded 5 (305.8(3) $\left.{ }^{\circ}\right)$.[13]

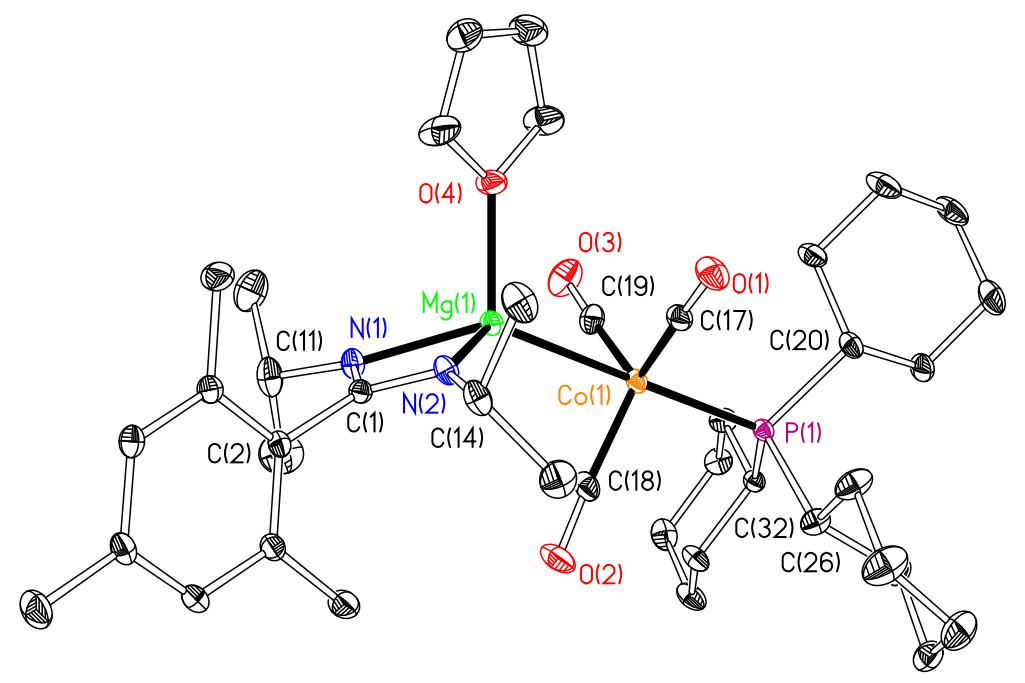

Figure 2. Displacement ellipsoid plot (25\% probability) of $\left\{\operatorname{MesC}\left(\mathrm{N}^{\mathrm{i}} \mathrm{Pr}\right)_{2}\right\} \operatorname{Mg}\left\{\mathrm{Co}(\mathrm{CO})_{3}\left(\mathrm{PCy}_{3}\right)\right\}(\mathrm{THF})(\mathbf{1 1}) . \mathrm{H}$ atoms omitted for clarity.

Table 1. Selected bond lengths $(\AA)$ and angles $\left(^{\circ}\right)$ for $\left\{\operatorname{MesC}\left(\mathrm{N}^{\mathrm{i}} \mathrm{Pr}\right)_{2}\right\} \operatorname{Mg}\left\{\mathrm{Co}(\mathrm{CO})_{3}(\mathrm{PCy})_{3}\right)(\mathrm{THF})$ (11).

$\begin{array}{llll}\mathrm{Mg}(1)-\mathrm{Co}(1) & 2.5310(7) & \mathrm{Mg}(1)-\mathrm{N}(1) & 2.0777(18) \\ \mathrm{Mg}(1)-\mathrm{N}(2) & 2.0498(17) & \mathrm{Mg}(1)-\mathrm{O}(4) & 2.0312(16) \\ \mathrm{Co}(1)-\mathrm{P}(1) & 2.2071(5) & \mathrm{Co}(1)-\mathrm{C}(17) & 1.745(2) \\ \mathrm{Co}(1)-\mathrm{C}(18) & 1.759(2) & \mathrm{Co}(1)-\mathrm{C}(19) & 1.745(2) \\ \mathrm{C}(1)-\mathrm{N}(1) & 1.332(3) & \mathrm{C}(1)-\mathrm{N}(2) & 1.327(3) \\ \mathrm{Co}(1)-\mathrm{Mg}(1)-\mathrm{N}(1) & 137.70(6) & \mathrm{Co}(1)-\mathrm{Mg}(1)-\mathrm{N}(2) & 120.64(6) \\ \mathrm{Co}(1)-\mathrm{Mg}(1)-\mathrm{O}(4) & 109.92(5) & \mathrm{N}(1)-\mathrm{Mg}(1)-\mathrm{N}(2) & 65.28(7) \\ \mathrm{N}(1)-\mathrm{Mg}(1)-\mathrm{O}(4) & 106.23(7) & \mathrm{N}(2)-\mathrm{Mg}(1)-\mathrm{O}(4) & 108.22(7) \\ \mathrm{Mg}(1)-\mathrm{Co}(1)-\mathrm{P}(1) & 174.58(2) & \mathrm{Mg}(1)-\mathrm{Co}(1)-\mathrm{C}(17) & 76.45(7) \\ \mathrm{Mg}(1)-\mathrm{Co}(1)-\mathrm{C}(18) & 80.87(7) & \mathrm{Mg}(1)-\mathrm{Co}(1)-\mathrm{C}(19) & 80.20(7) \\ \mathrm{P}(1)-\mathrm{Co}(1)-\mathrm{C}(17) & 99.02(7) & \mathrm{P}(1)-\mathrm{Co}(1)-\mathrm{C}(18) & 98.62(7) \\ \mathrm{P}(1)-\mathrm{Co}(1)-\mathrm{C}(19) & 104.63(7) & \mathrm{C}(17)-\mathrm{Co}(1)-\mathrm{C}(18) & 115.17(10) \\ \mathrm{C}(17)-\mathrm{Co}(1)-\mathrm{C}(19) & 115.48(11) & \mathrm{C}(18)-\mathrm{Co}(1)-\mathrm{C}(19) & 119.07(11) \\ \mathrm{N}(1)-\mathrm{C}(1)-\mathrm{N}(2) & 113.75(17) & & \end{array}$

The solid state IR spectrum of $\mathbf{1 1}$ shows three main higher frequency $v(\mathrm{CO})$ bands at 1963, 1922 and $1879 \mathrm{~cm}^{-1}$ and no significant lower frequency $v(\mathrm{CO})$ bands, consistent with a $\mathrm{Mg}-\mathrm{Co}$ bonded structure without $\mathrm{Mg}(\mu-\mathrm{OC}) \mathrm{Co}$ isocarbonyl bridging. The solution IR spectrum of $\mathbf{1 1}$ in toluene is 
more complicated with three $v(\mathrm{CO})$ bands at 1969, 1904 and $1895 \mathrm{~cm}^{-1}$, attributed to a $\mathrm{Mg}-\mathrm{Co}$ bonded species, and lower frequency bands at 1839 and $1755 \mathrm{~cm}^{-1}$, possibly indicative of more complex behaviour in solution.

Reaction of 9 with K[Fp] in THF- $d_{8}$ on the NMR tube-scale showed quantitative formation of $\left\{\operatorname{MesC}\left(\mathrm{N}^{\mathrm{i}} \mathrm{Pr}\right)_{2}\right\} \mathrm{MgFp}(\mathrm{THF})$ by ${ }^{1} \mathrm{H}$ NMR spectroscopy. However, benzene extraction during the preparative scale reaction resulted in a complex mixture of products, evidenced by the presence of multiple ligand environments and $\mathrm{Fp}_{2}$ in the ${ }^{1} \mathrm{H}$ NMR spectrum, the latter being a common decomposition product in the chemistry of the [Fp] anion.[23] Given the stability of $\mathbf{1 1}$ in a nondonor solvent, the apparent decomposition of the desired $\mathrm{Mg}-\mathrm{Fe}$ bonded species was somewhat unexpected. Of note is that the related $\mathbf{8}$ is also successfully isolated via a benzene extraction. It was postulated that substituting the N-bound ${ }^{\mathrm{i}} \mathrm{Pr}$ groups for more sterically demanding Dipp or Mes (Mes $=2,4,6$-trimethylphenyl) groups would improve the overall complex stability and allow isolation of an amidinate $\mathrm{Mg}-\mathrm{Fe}$, alongside $\mathrm{Mg}-\mathrm{Co}$, bonded complex.

The synthesis of the required carbodiimide, DippNCNDipp (12), has been reported in the literature previously, albeit on a relatively small scale, from the reaction of $\operatorname{Dipp}(\mathrm{H}) \mathrm{NC}(\mathrm{S}) \mathrm{N}(\mathrm{H}) \operatorname{Dipp}$ with $\mathrm{HgO} / \mathrm{MgSO}_{4}$. [24] A report by Patel et al. details the conversion of arylthioureas to carbodiimides via reaction with $I_{2}$ in the presence of $\mathrm{NEt}_{3}$.[25] Using this general procedure Dipp(H)NC(S)N(H)Dipp was converted to 12. However, the carbodiimide was contaminated with residual elemental sulfur. A modified procedure was therefore developed based on a report by Blumer[26] in which the contaminated hydrocarbon solution of carbodiimide was treated with an excess of activated $\mathrm{Cu}$, thereby removing the elemental sulfur as insoluble $\mathrm{CuS}$ and giving $\mathbf{1 2}$ in $65 \%$ isolated yield.

Reaction of 12 with $\mathrm{MesMgBr}$ in $\mathrm{Et}_{2} \mathrm{O}$ gave [ $\left.\left\{\mathrm{MesC}(\mathrm{NDipp})_{2}\right\} \mathrm{Mg}(\mu-\mathrm{Br})\left(\mathrm{OEt}_{2}\right)\right]_{2}(\mathbf{1 3})$ in $67 \%$ isolated yield. Whilst crystalline samples of $\mathbf{1 3}$ could be isolated these were not suitable for analysis by single crystal X-ray diffraction. Reaction of 13 with $\mathrm{K}\left[\mathrm{Co}(\mathrm{CO})_{3}\left(\mathrm{PCy}_{3}\right)\right](\mathrm{THF})_{2}$ in THF followed by pentane extraction gave $\left\{\mathrm{MesC}(\mathrm{NDipp})_{2}\right\} \mathrm{Mg}\left\{\mathrm{Co}(\mathrm{CO})_{3}\left(\mathrm{PCy}_{3}\right)\right\}(\mathrm{THF})(\mathbf{1 4})$ as a grey solid in $39 \%$ isolated yield. Diffraction quality crystals of $\mathbf{1 4}$ were grown from a benzene solution at room temperature. The structure of $\mathbf{1 4}$ is monomeric in the solid state (Fig. 3) containing a four-coordinate magnesium centre with approximately tetrahedral geometry. Somewhat surprisingly the Mg-Co distance (2.5193(5) $\AA$ ) in $\mathbf{1 4}$ is shorter than that observed in $\mathbf{1 1}$ which features less bulky $\mathrm{N}-{ }^{\mathrm{i}} \mathrm{Pr}$ substituents on the amidinate ligand. This can be attributed to one or two different effects. First, the orientation of the Dipp groups in $\mathbf{1 4}$ away from the metal anion. In the case of $\mathbf{1 1}$ the ${ }^{\mathrm{i}} \mathrm{Pr}$ substituents orient themselves such that the Me groups are pointing away from the Mes group and towards the Co centre, potentially increasing the $\mathrm{Mg}$ - Co distance as a result. This effect may be viewed as an extension of that reported by Jordan et al. for steric repulsion within sterically demanding amidinate aluminium systems.[27] In addition, the $\mathrm{N}$-aryl substituted ligand in $\mathbf{1 4}$ gives a more electrophilic $\mathbf{M g}$ centre than the $\mathrm{N}$-alkyl 
functionalised ligand in 11. Consistent with this, the $\mathrm{Mg}-\mathrm{N}$ distances are shorter in 11 (2.0498(17) and 2.0777(18) $\AA$ ) than $14(2.0590(12)$ and 2.0983(13) $\AA$ ), and hence the $\mathrm{N}(1)-\mathrm{Mg}(1)-\mathrm{N}(2)$ biteangle in $14\left(64.51(5)^{\circ}\right)$ is slightly more acute than in $11\left(65.28(7)^{\circ}\right)$. For $14 \sum(\mathrm{P}-\mathrm{Co}-\mathrm{CO})=$ $301.37(9)^{\circ}$, very similar to that for $\mathbf{1 1}\left(302.27(12)^{\circ}\right)$, indicative of a significant interaction between the metal centres.

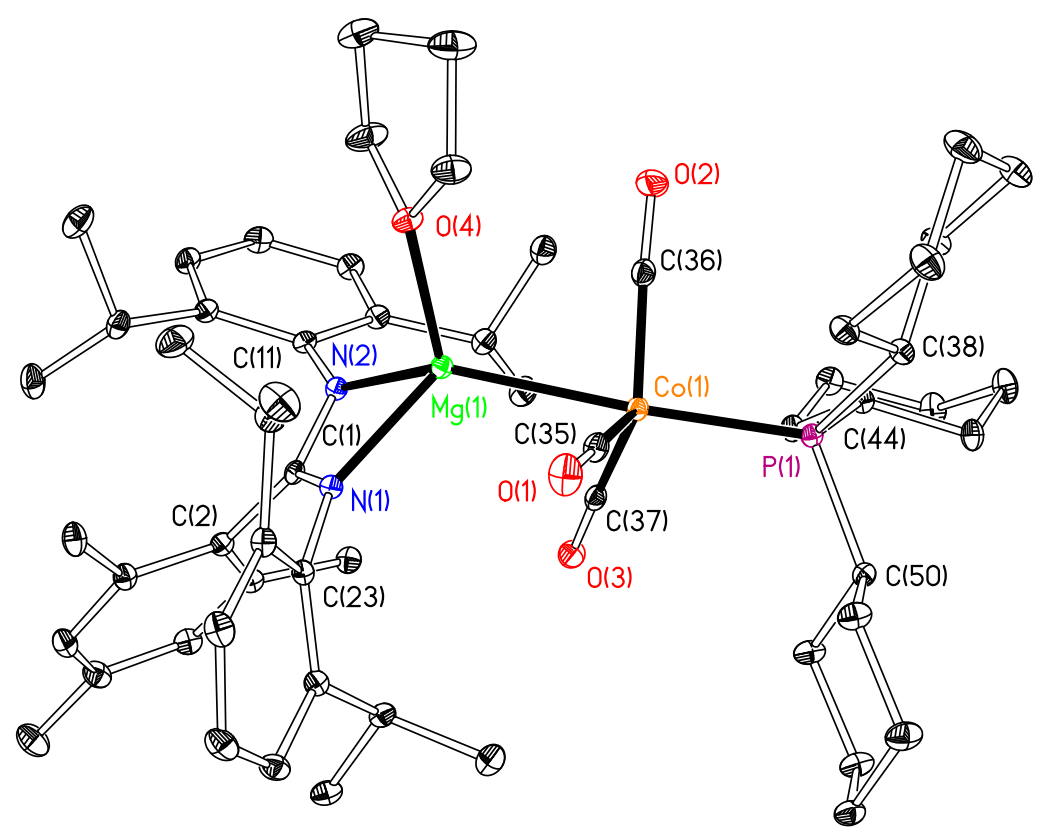

Figure 3. Displacement ellipsoid plot $(25 \%$ probability $)$ of $\left\{\mathrm{MesC}(\mathrm{NDipp})_{2}\right\}\left\{\mathrm{MgCo}(\mathrm{CO})_{3}\left(\mathrm{PCy}_{3}\right)\right\}(\mathrm{THF})(\mathbf{1 4})$. $\mathrm{H}$ atoms and independent molecule of protioligand omitted for clarity.

Table 2. Selected bond lengths $(\AA)$ and angles $\left(^{\circ}\right)$ for $\left\{\operatorname{MesC}(\operatorname{Dipp})_{2}\right\} \operatorname{Mg}\left\{\operatorname{Co}(\mathrm{CO})_{3}\left(\mathrm{PCy}_{3}\right)\right\}(\mathrm{THF})$ (14).

$\begin{array}{llll}\mathrm{Mg}(1)-\mathrm{Co}(1) & 2.5193(5) & \mathrm{Mg}(1)-\mathrm{N}(1) & 2.0590(12) \\ \mathrm{Mg}(1)-\mathrm{N}(2) & 2.0983(13) & \mathrm{Mg}(1)-\mathrm{O}(4) & 2.0317(11) \\ \mathrm{Co}(1)-\mathrm{P}(1) & 2.2026(4) & \mathrm{Co}(1)-\mathrm{C}(35) & 1.7580(16) \\ \mathrm{Co}(1)-\mathrm{C}(36) & 1.7494(16) & \mathrm{Co}(1)-\mathrm{C}(37) & 1.7605(16) \\ \mathrm{C}(1)-\mathrm{N}(1) & 1.3356(17) & \mathrm{C}(1)-\mathrm{N}(2) & 1.3531(18) \\ \mathrm{Co}(1)-\mathrm{Mg}(1)-\mathrm{N}(1) & 118.74(4) & \mathrm{Co}(1)-\mathrm{Mg}(1)-\mathrm{N}(2) & 134.60(4) \\ \mathrm{Co}(1)-\mathrm{Mg}(1)-\mathrm{O}(4) & 109.46(4) & \mathrm{N}(1)-\mathrm{Mg}(1)-\mathrm{N}(2) & 64.51(5) \\ \mathrm{N}(1)-\mathrm{Mg}(1)-\mathrm{O}(4) & 116.86(5) & \mathrm{N}(2)-\mathrm{Mg}(1)-\mathrm{O}(4) & 106.64(5) \\ \mathrm{Mg}(1)-\mathrm{Co}(1)-\mathrm{P}(1) & 174.780(18) & \mathrm{Mg}(1)-\mathrm{Co}(1)-\mathrm{C}(35) & 80.37(5) \\ \mathrm{Mg}(1)-\mathrm{Co}(1)-\mathrm{C}(36) & 80.13(5) & \mathrm{Mg}(1)-\mathrm{Co}(1)-\mathrm{C}(37) & 78.54(5) \\ \mathrm{P}(1)-\mathrm{Co}(1)-\mathrm{C}(35) & 104.51(5) & \mathrm{P}(1)-\mathrm{Co}(1)-\mathrm{C}(36) & 95.89(5) \\ \mathrm{P}(1)-\mathrm{Co}(1)-\mathrm{C}(37) & 100.97(5) & \mathrm{C}(35)-\mathrm{Co}(1)-\mathrm{C}(36) & 116.22(7)\end{array}$




\begin{tabular}{|c|c|c|}
\hline$C(35)-\operatorname{Co}(1)-C(37)$ & $112.35(7)$ & $\mathrm{C}(36)-\mathrm{Co}(1)-\mathrm{C}(37)$ \\
\hline $\mathrm{N}(1)-\mathrm{C}(1)-\mathrm{N}(2)$ & $111.23(12)$ & \\
\hline
\end{tabular}

The solid state IR spectrum of $\mathbf{1 4}$ shows two strong $\mathrm{v}(\mathrm{CO})$ bands at 1965 and $1873 \mathrm{~cm}^{-1}$, the latter of which is broad and may comprise two overlapping bands. There are no $v(\mathrm{CO})$ bands at lower frequencies, indicating an absence of isocarbonyl interactions in the solid state. The solution IR of $\mathbf{1 4}$ in toluene shows only three $v(\mathrm{CO})$ bands at 1968,1891 and $1840 \mathrm{~cm}^{-1}$, consistent with preservation of the $\mathrm{Mg}-\mathrm{Co}$ bond in solution.

Reaction of $\mathbf{1 3}$ with $\mathrm{K}[\mathrm{Fp}]$ in $\mathrm{THF}$ followed by benzene extraction gave $\{$ MesC(NDipp) 2$\} \operatorname{MgFp}(\mathrm{THF})(\mathbf{1 5})$ as a light brown solid in $74 \%$ yield. This is in contrast to the attempted reaction of 9 with $\mathrm{K}[\mathrm{Fp}]$ to form $\left\{\mathrm{MesC}\left(\mathrm{N}^{\mathrm{i}} \mathrm{Pr}\right)_{2}\right\} \mathrm{MgFp}(\mathrm{THF})$ which was unstable in nondonor solvent. Although diffraction quality crystals of $\mathbf{1 5}$ could not be grown, ${ }^{1} \mathrm{H}$ and ${ }^{13} \mathrm{C}\left\{{ }^{1} \mathrm{H}\right\} \mathrm{NMR}$ spectroscopic data are consistent with formation of the desired species. A diffusion NMR spectroscopic study of $\mathbf{1 5}$ (see below) suggests that it is monomeric in toluene. The solid state IR spectrum of 15 shows four $v(\mathrm{CO})$ bands; two strong bands at 1930 and 1866 and medium intensity bands at 1961 and $1791 \mathrm{~cm}^{-1}$. The solution IR spectrum of $\mathbf{1 5}$ in toluene shows two $v(\mathrm{CO})$ bands at 2017 and $1925 \mathrm{~cm}^{-1}$ consistent with a non-isocarbonyl bridged species in the solution phase. For comparison, the solution IR spectrum of structurally authenticated $\mathrm{Mg}-\mathrm{Fe}$ bonded $\mathbf{8}$ in toluene was recorded and showed two $v(\mathrm{CO})$ bands at 2017 and $1925 \mathrm{~cm}^{-1}$. The similar position of the $v(\mathrm{CO})$ bands in $\mathbf{8}$ and $\mathbf{1 5}$ strongly support the latter as being $\mathrm{Mg}-\mathrm{Fe}$ bonded in solution.

MesNCNMes (16) was synthesised from $\operatorname{Mes}(\mathrm{H}) \mathrm{NC}(\mathrm{S}) \mathrm{N}(\mathrm{H}) \mathrm{Mes}$ using an analogous procedure to that employed for $\operatorname{Dipp}(\mathrm{H}) \mathrm{NC}(\mathrm{S}) \mathrm{N}(\mathrm{H}) \operatorname{Dipp}$. Reaction of $\mathbf{1 6}$ with $\mathrm{MesMgBr}$ in $\mathrm{Et}_{2} \mathrm{O}$ gave $\left.\left[\{\text { MesC(NMes) })_{2}\right\} \operatorname{Mg}(\mu-\mathrm{Br})\left(\mathrm{OEt}_{2}\right)\right]_{2}(\mathbf{1 7})$ in $93 \%$ isolated yield. Diffraction quality crystals of $\mathbf{1 7}$ were grown from an $\mathrm{Et}_{2} \mathrm{O}$ solution at $5{ }^{\circ} \mathrm{C}$. X-ray crystallographic studies confirmed $\mathbf{1 7}$ as having a dimeric structure in the solid state, very similar to that observed for $\mathbf{9}$. The solid state structure of $\mathbf{1 7}$ and a table containing selected distances and angles for $\mathbf{9}$ and $\mathbf{1 7}$ is presented in the SI. ${ }^{1} \mathrm{H}$ NMR analysis of crystals of $\mathbf{1 7}$ grown from $\mathrm{Et}_{2} \mathrm{O}$ shows one equivalent of $\mathrm{Et}_{2} \mathrm{O}$ per ligand. However, prolonged drying of the bulk material in vacuo leads to loss of $\mathrm{Et}_{2} \mathrm{O}$ and two distinct ligand environments when observed in $\mathrm{C}_{6} \mathrm{D}_{6}$. In contrast, the ${ }^{1} \mathrm{H}$ NMR spectrum recorded for 17 in THF- $d_{8}$ shows only one set of ligand environments consistent with a monomeric structure with equivalent N-Mes environments.

Reaction of 17 with $\mathrm{K}\left[\mathrm{Co}(\mathrm{CO})_{3}\left(\mathrm{PCy}_{3}\right)\right](\mathrm{THF})_{2}$ in $\mathrm{THF}$ followed by benzene extraction gave $\left.\{\text { MesC(NMes })_{2}\right\} \operatorname{Mg}\left\{\mathrm{Co}(\mathrm{CO})_{3}\left(\mathrm{PCy}_{3}\right)\right\}(\mathrm{THF})(\mathbf{1 8})$ as a white solid in $84 \%$ isolated yield. The solid state IR spectrum of $\mathbf{1 8}$ shows a large number of $v(\mathrm{CO})$ bands at 1964, 1937, 1885, 1865 and 1720 $\mathrm{cm}^{-1}$. Comparison with the IR data for 14 suggests that those at 1964,1885 and $1865 \mathrm{~cm}^{-1}$ are attributable to the $\mathrm{A}_{1-}$ and two E-type $v(\mathrm{CO})$ stretching modes of the monomeric $\mathrm{Mg}$ - Co complex. The peaks at 1937 and $1720 \mathrm{~cm}^{-1}$ are likely the result of a secondary species which exhibits $\operatorname{Mg}(\mu-$ 
OC)Co isocarbonyl interactions. The solution IR spectrum of $\mathbf{1 8}$ in toluene shows $v(\mathrm{CO})$ bands at $1970,1910,1890,1836$ and $1755 \mathrm{~cm}^{-1}$, again consistent with two species with at least one band in the range indicating an isocarbonyl interaction. These data are in contrast to that of $\mathbf{1 4}$, which showed no significant low frequency $v(\mathrm{CO})$ bands in solution or the solid state, and was confirmed to be $\mathrm{Mg}-\mathrm{Co}$ bonded by X-ray crystallography.

The reaction of $\mathbf{1 7}$ with $\mathrm{K}[\mathrm{Fp}]$ in $\mathrm{THF}$ followed by benzene extraction gave $\left.\{\text { MesC(NMes) })_{2}\right\} \operatorname{MgFp}(\mathrm{THF})$ (19) by ${ }^{1} \mathrm{H}$ NMR spectroscopy, albeit accompanied by other ligand environments. This susceptibility to decomposition in non-donor solvents was also observed for the product of the reaction between 9 and $\mathrm{K}[\mathrm{Fp}]$. To combat this decomposition the procedure was modified to use THF as the only solvent. This allowed isolation of $\left\{\mathrm{MesC}(\mathrm{NMes})_{2}\right\} \mathrm{MgFp}(\mathrm{THF})$ (19) as a light brown solid in $68 \%$ isolated yield. The solid state IR spectrum of $\mathbf{1 9}$ showed two main $v(\mathrm{CO})$ bands at 1923 and $1858 \mathrm{~cm}^{-1}$, notably absent are lower frequency $v(\mathrm{CO})$ bands that would indicate the presence of isocarbonyl interactions. The solution IR spectrum of $\mathbf{1 9}$ in THF is more complicated but nonetheless dominated by $v(\mathrm{CO})$ bands at 1921 and $1861 \mathrm{~cm}^{-1}$. Reassuringly, the previously reported solution IR spectrum of $\mathrm{Mg}-\mathrm{Fe}$ bonded $\mathbf{8}$ in THF similarly shows bands at 1926 and $1871 \mathrm{~cm}^{-1} \cdot[19]$

\subsection{Magnesium guanidinate complexes}

Guanidinate ligands $\left(\mathrm{R}_{2}^{\prime} \mathrm{NC}(\mathrm{NR})_{2}\right)$ are structurally and geometrically very similar to amidinate ligands but have subtly different electronic properties as a result of the distal nitrogen. Donation of electron density from this nitrogen has the ultimate effect of increasing the overall ligand Lewis basicity, potentially increasing the strength of interaction with the Lewis acidic Ae centre and overall complex stability as a result.[28] Given our successful synthesis of Mg-TM complexes using the Dipp substituents in both our NacNac and aforementioned amidinate systems we selected this for the $\mathrm{R}$-group in these complexes. Whilst a range of bulky $\mathrm{R}^{\prime}$ groups for the distal nitrogen have been reported,[21a] these offer little steric protection at the $\mathrm{Mg}$ centre and primarily have a solubilising effect. Therefore, given the solubilising R-groups already selected, we opted for a simple $\mathrm{NMe}_{2}$ group.

Reaction of $\mathrm{LiNMe}_{2}$ with DippNCNDipp, followed by an aqueous workup gave the protio-ligand $\mathrm{Me}_{2} \mathrm{NC}(\mathrm{NDipp}$ (NHDipp) (20) as a white solid in 69\% isolated yield. Crystals of 20 suitable for analysis by X-ray diffraction were grown from a hexane solution at RT. The structure of $\mathbf{2 0}$ and selected distances and angles are presented in the SI. 


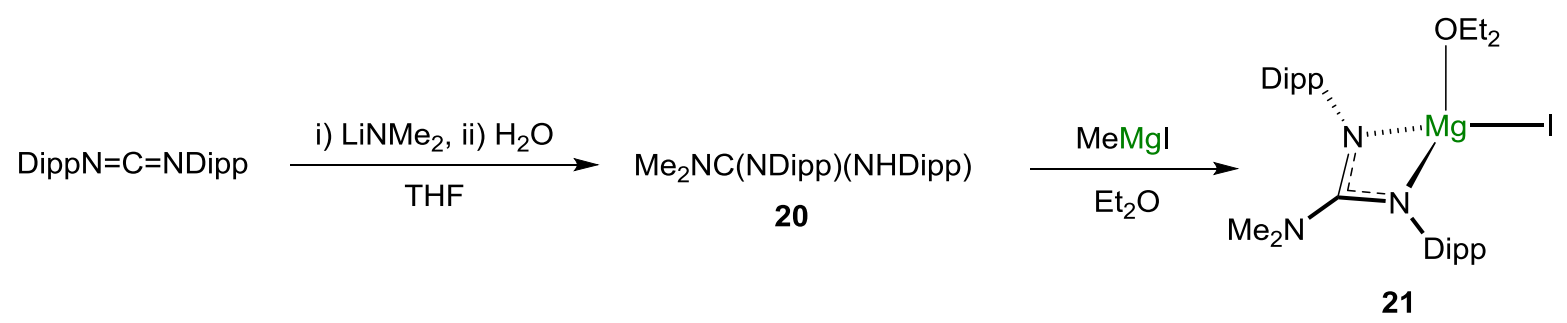

Scheme 2. Synthesis of $\left\{\mathrm{Me}_{2} \mathrm{NC}(\mathrm{NDipp})_{2}\right\} \mathrm{MgI}\left(\mathrm{OEt}_{2}\right)(\mathbf{2 1})$.

Reaction of 20 with MeMgI afforded $\left\{\mathrm{Me}_{2} \mathrm{NC}(\mathrm{NDipp})_{2}\right\} \mathrm{MgI}\left(\mathrm{OEt}_{2}\right)(\mathbf{2 1})$ as a white solid in $95 \%$ isolated yield. Crystals of $\mathbf{2 1}$ suitable for analysis by X-ray diffraction were grown from benzene at room temperature. The structure of $\mathbf{2 1}$, shown in Fig. 4, has a four-coordinate $\mathrm{Mg}$ centre with approximately tetrahedral coordination geometry, with two $\mathrm{Mg}-\mathrm{N}$ bonds to the bidentate guanidinate ligand and one bond to each of the iodine and ether ligand. The $\mathrm{N}(1)-\mathrm{Mg}(1)-\mathrm{N}(2)$ bite-angle $\left(66.86(13)^{\circ}\right)$ is similar to that for the structurally similar (Priso) $\mathrm{Mg}(\mu-\mathrm{I})_{2} \mathrm{Mg}\left(\mathrm{OEt}_{2}\right)(\operatorname{Priso})\left(66.47(8)^{\circ}\right.$, Priso $\left.={ }^{\mathrm{i}} \mathrm{Pr}_{2} \mathrm{NC}(\mathrm{NDipp})_{2}\right)$ reported by Jones et al.[3] It is also similar to the aforementioned $\mathrm{Mg}-\mathrm{Br}$ (9: 64.29(6), 17: 63.44(6) $)^{\circ}$ and $\mathrm{Mg}-\mathrm{Co}\left(11: 65.28(7), 14: 64.51(5)^{\circ}\right)$ bonded amidinate complexes consistent with the concept of a similar geometry despite substitution of a mesityl for the more electron-donating $\mathrm{NMe}_{2}$ group.

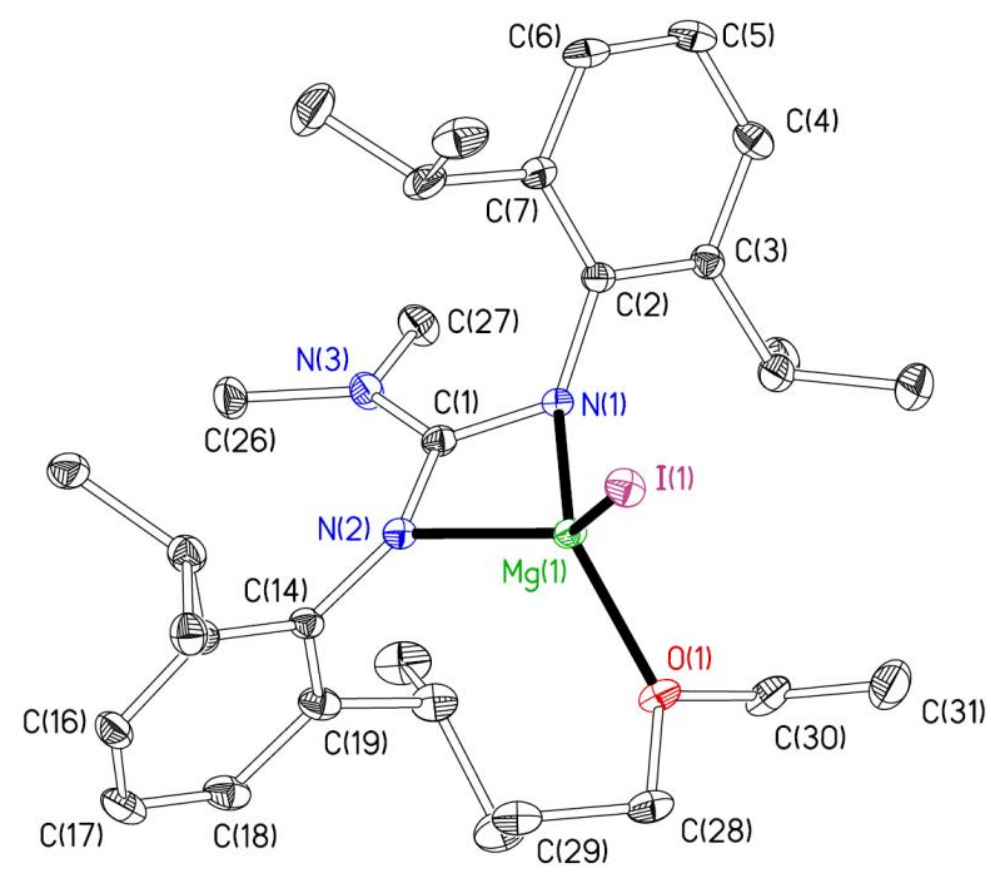

Figure 4. Displacement ellipsoid plot (20\% probability) of $\left\{\mathrm{Me}_{2} \mathrm{NC}(\mathrm{NDipp})_{2}\right\} \mathrm{MgI}\left(\mathrm{OEt}_{2}\right)(\mathbf{2 1})$. $\mathrm{H}$ atoms omitted for clarity. Selected distances $(\AA)$ and angles $\left(^{\circ}\right): \operatorname{Mg}(1)-\mathrm{I}(1) 2.6500(13), \operatorname{Mg}(1)-\mathrm{N}(1)$ 2.052(3), $\mathrm{Mg}(1)-\mathrm{N}(2)$ 2.040(3), $\mathrm{Mg}(1)-\mathrm{O}(1)$ 2.029(3), N(1)-Mg(1)-N(2) 66.86(13), N(1)-C(1)-N(2) $112.8(3)$.

Initial attempts to synthesise $\left[\left\{\mathrm{Me}_{2} \mathrm{NC}(\mathrm{NDipp})_{2}\right\} \mathrm{MgFp}(\mathrm{THF})_{\mathrm{x}}\right]_{\mathrm{n}}$ by reacting 21 with $\mathrm{K}[\mathrm{Fp}]$ in $\mathrm{THF}$ were unsuccessful. Analysis of this reaction on the NMR-tube scale showed there to be no conversion 
to the desired product, contrasting with the syntheses of $\mathbf{8}$ and $\mathbf{1 5}$, which proceeded under ambient conditions. Gratifyingly however, repeating the reaction on the NMR tube-scale in $\mathrm{C}_{6} \mathrm{D}_{6}$ gave quantitative conversion to $\left[\left\{\mathrm{Me}_{2} \mathrm{NC}(\mathrm{NDipp})_{2}\right\} \mathrm{MgFp}_{2}\right.$ (22) by ${ }^{1} \mathrm{H} \mathrm{NMR}$. The reaction was scaled-up, affording 22 as a yellow solid in $64 \%$ isolated yield (Scheme 3 ).

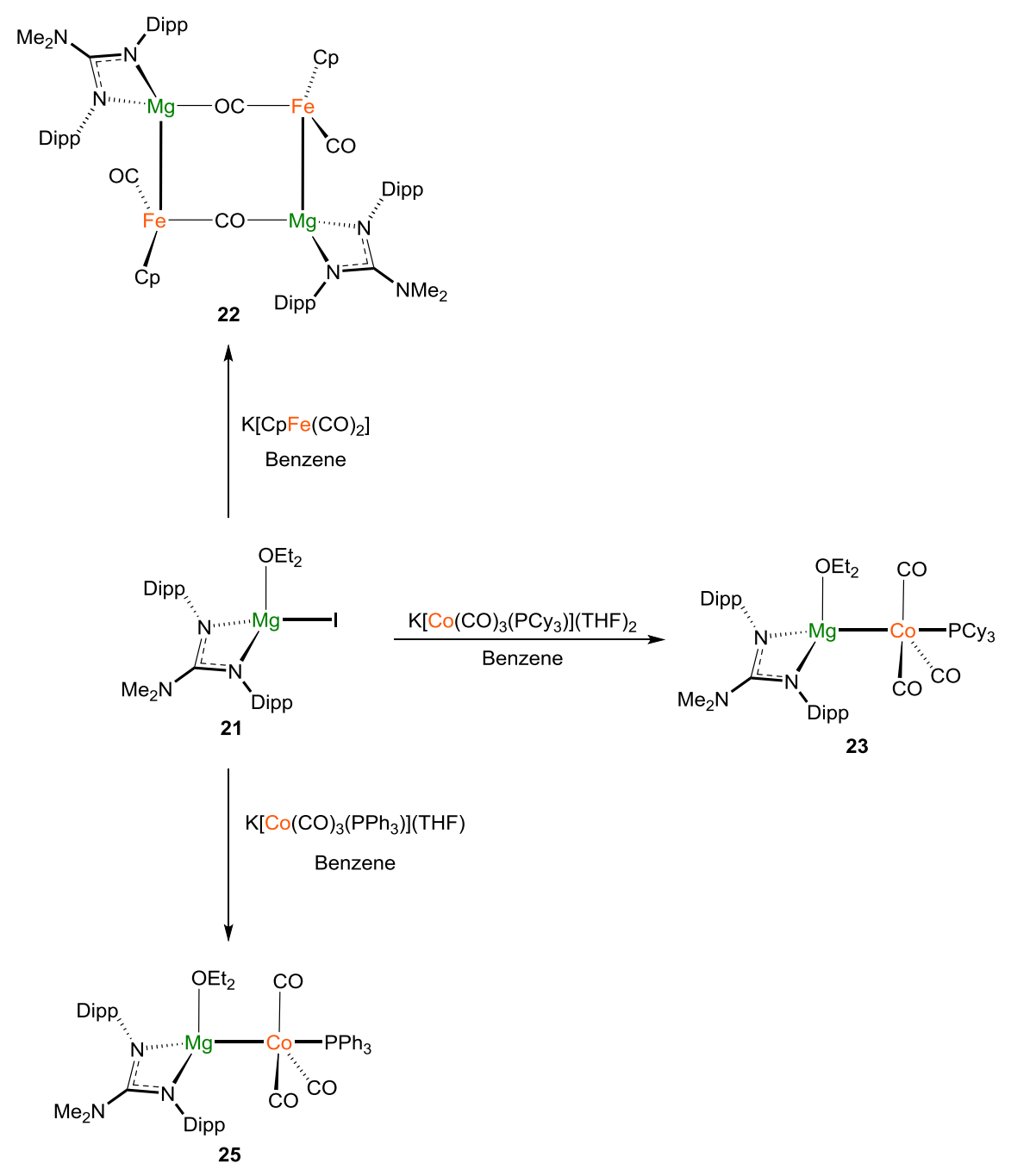

Scheme 3. Synthesis of guanidinate $\mathrm{Mg}-\mathrm{Fe}$ bonded 22 and $\mathrm{Mg}-\mathrm{Co}$ bonded 23 and 25 from 21.

Crystals of 22 suitable for analysis by X-ray diffraction were grown from a benzene solution at $5{ }^{\circ} \mathrm{C}$. The structure is shown in Fig. 5 and selected distances and angles in Table 3. Complex 22 crystallises as a dimer in the solid state with two $\mathrm{Mg}-\mathrm{Fe}$ bonds and two $\mathrm{Mg}(\mu-\mathrm{OC}) \mathrm{Fe}$ linkages. Each $\mathrm{Mg}$ centre is four-coordinate with an approximately tetrahedral geometry. The $\mathrm{Mg}-\mathrm{Fe}$ bond distances (2.5279(4) $\AA$ ) are shorter than those in monomeric 8 (2.6326(4) A), [19] which also features a considerably larger bite-angle compared to $22\left(90.97(4) v s .66 .00(4)^{\circ}\right)$. The $\mathrm{Mg}-\mathrm{Fe}$ distances are also shorter than those in dimeric $6(2.6112(5) \& 2.5629(5) \AA)$, which does not feature a sterically demanding supporting ligand. Being shorter than those in Felkin's 1 (2.593(7) $\AA$ ),[7] the $\mathrm{Mg}-\mathrm{Fe}$ distances in 22 are the shortest reported to date.[14] 


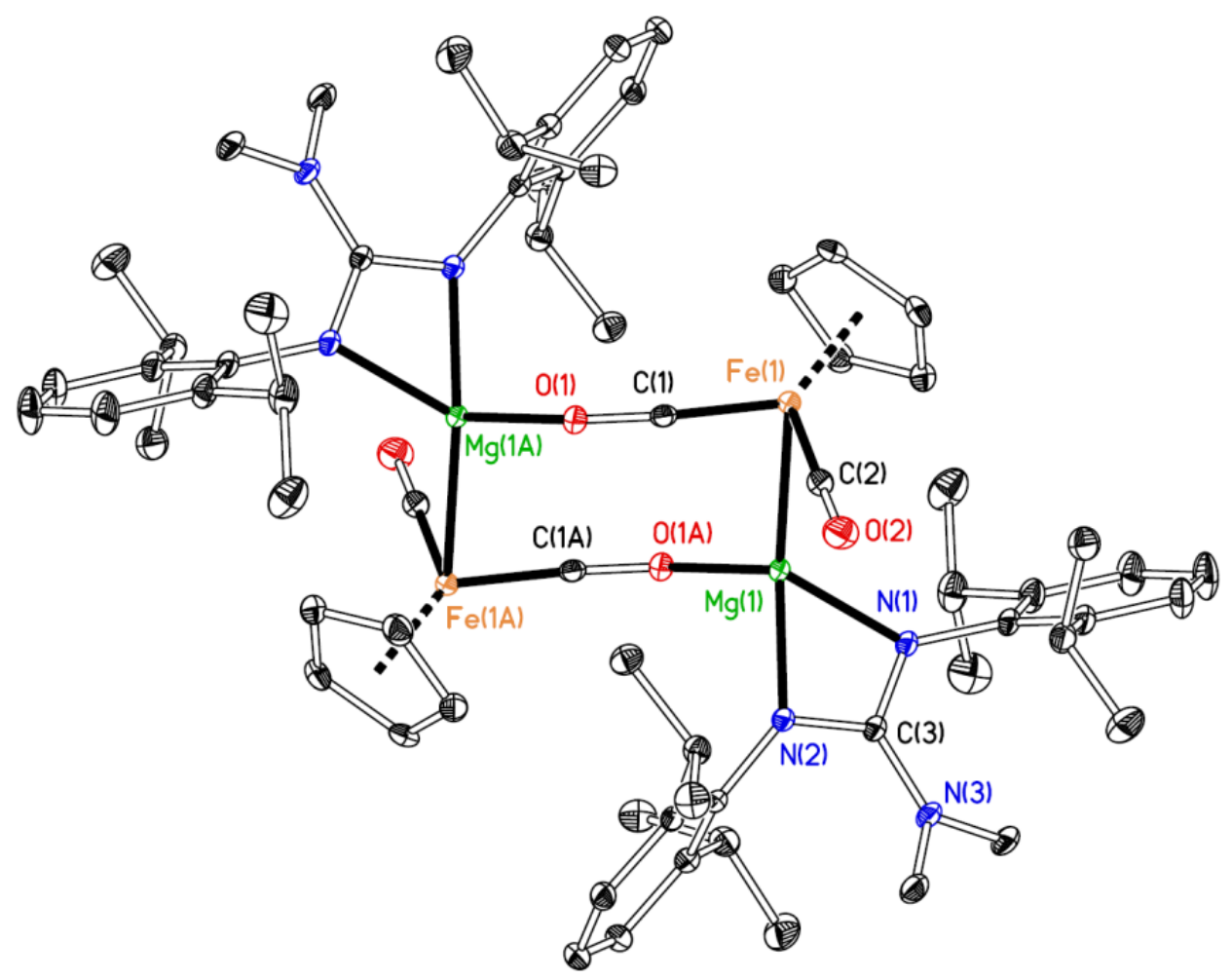

Figure 5. Displacement ellipsoid plot (20\% probability) of [ $\left.\left\{\mathrm{Me}_{2} \mathrm{NC}(\mathrm{NDipp})_{2}\right\} \mathrm{MgFp}\right]_{2}(\mathbf{2 2})$. $\mathrm{H}$ atoms and solvent of crystallisation omitted for clarity. Atoms carrying the suffix 'A' are related to their counterparts by the symmetry operator 1-x, 1-y, 1-z.

Table 3. Selected bond lengths $(\AA)$ and angles $\left(^{\circ}\right)$ for $\left[\left\{\mathrm{Me}_{2} \mathrm{NC}(\mathrm{NDipp})_{2}\right\} \mathrm{MgFp}\right]_{2}(\mathbf{2 2})$.

\begin{tabular}{llll}
\hline $\mathrm{Mg}(1)-\mathrm{Fe}(1)$ & $2.5279(4)$ & $\mathrm{Mg}(1)-\mathrm{O}(1 \mathrm{~A})$ & $2.0552(10)$ \\
$\mathrm{Mg}(1)-\mathrm{N}(1)$ & $2.0620(10)$ & $\mathrm{Mg}(1)-\mathrm{N}(2)$ & $2.0627(10)$ \\
$\mathrm{Fe}(1)-\mathrm{C}(1)$ & $1.6985(12)$ & $\mathrm{Fe}(1)-\mathrm{C}(2)$ & $1.7469(14)$ \\
$\mathrm{Fe}(1)-\mathrm{Mg}(1)-\mathrm{O}(1 \mathrm{~A})$ & $108.46(3)$ & $\mathrm{Fe}(1)-\mathrm{Mg}(1)-\mathrm{N}(1)$ & $121.23(3)$ \\
$\mathrm{Fe}(1)-\mathrm{Mg}(1)-\mathrm{N}(2)$ & $137.58(3)$ & $\mathrm{N}(1)-\mathrm{Mg}(1)-\mathrm{N}(2)$ & $66.00(4)$ \\
$\mathrm{N}(1)-\mathrm{C}(3)-\mathrm{N}(2)$ & $113.05(10)$ & & \\
\hline
\end{tabular}

The absence of a coordinated donor solvent in $\mathbf{2 2}$, that is, it is isolated "base-free", is notable. All reported $\mathrm{Mg}-\mathrm{Fe}$ bonded complexes to date have THF bonded by virtue of their syntheses. Indeed the only structurally authenticated base-free Ae-TM bonded complex reported to date is Jones' $\mathrm{Mg}-\mathrm{Mn}$ bonded ( $\left.{ }^{\mathrm{Mes}} \mathrm{NacNac}\right) \mathrm{MgMnN}\left(\mathrm{Ar}^{*}\right) \mathrm{Si}^{\mathrm{i}} \mathrm{Pr}_{3} \quad\left(\mathrm{Ar}^{*}=\mathrm{C}_{6} \mathrm{H}_{2}\left\{\mathrm{C}(\mathrm{H}) \mathrm{Ph}_{2}\right\}_{2}{ }^{\mathrm{i}} \mathrm{Pr}-2,6,4\right)$ synthesised by the reaction of $\left[\left({ }^{\mathrm{Mes}} \mathrm{NacNac}\right) \mathrm{Mg}\right]_{2}$ with $\left[\left({ }^{\mathrm{Mes}} \mathrm{NacNac}\right) \mathrm{Mn}(\mu-\mathrm{Br})(\mathrm{THF})\right]_{2}$ in cyclohexane.[29] The lack of coordinated $\mathrm{Et}_{2} \mathrm{O}$ in the bulk sample of $\mathbf{2 2}$ is confirmed by the absence of signals attributable to $\mathrm{Et}_{2} \mathrm{O}$ in the ${ }^{1} \mathrm{H}$ or ${ }^{13} \mathrm{C}\left\{{ }^{1} \mathrm{H}\right\}$ NMR spectra. Our recent findings have shown the presence of coordinated donor groups to be potentially very disruptive to Ae-TM bonding, favouring the formation of isocarbonyl linkages and in extreme cases separated ion pairs.[13] Therefore, to isolate a base-free 
Ae-TM bonded complex is significant and may enable enhanced reactivity in future studies. To investigate the potential interaction of $\mathbf{2 2}$ with THF, a sample of 22 was dissolved in THF then volatiles removed under reduced pressure and the solid dried in vacuo. ${ }^{1} \mathrm{H}$ NMR analysis showed there to be no THF present. This lack of coordination and therefore maintenance of the dimeric structure is somewhat remarkable but would appear to be the exception rather than rule for the series of guanidinate complexes investigated in this study (see below). The solid state IR spectrum of 22 shows two main $v(\mathrm{CO})$ bands at 1944 and $1778 \mathrm{~cm}^{-1}$. The former is attributed to the terminal carbonyl and latter to the isocarbonyl groups, consistent with the structure determined by X-ray crystallography. The solution IR spectrum of 22 in toluene also shows a low frequency $v(\mathrm{CO})$ band at $1781 \mathrm{~cm}^{-1}$, consistent with isocarbonyl interactions in solution. The solution IR spectrum in THF was dominated by two major $v(\mathrm{CO})$ bands (2014 and $1946 \mathrm{~cm}^{-1}$ ) consistent with dissociation to a monomeric structure without isocarbonyl bridging, most probably a THF adduct.

Given the successful synthesis of $\mathbf{2 2}$ in benzene, this was also attempted for the reaction between 21 and $\mathrm{K}\left[\mathrm{Co}(\mathrm{CO})_{3}\left(\mathrm{PCy}_{3}\right)\right](\mathrm{THF})_{2}$, giving $\left\{\mathrm{Me}_{2} \mathrm{NC}(\mathrm{NDipp})_{2}\right\} \mathrm{Mg}\left\{\mathrm{Co}(\mathrm{CO})_{3}\left(\mathrm{PCy}_{3}\right)\right\}\left(\mathrm{OEt}_{2}\right)$ (23) as a red solid in $68 \%$ isolated yield. Crystals of $\mathbf{2 3}$ suitable for analysis by X-ray crystallography could not be obtained. However, unlike 22, the presence of one coordinated $\mathrm{Et}_{2} \mathrm{O}$ per set of ligand environments is apparent by ${ }^{1} \mathrm{H}$ NMR spectroscopy. Low frequency $v(\mathrm{CO})$ bands are absent in the solid state IR spectrum, consistent with no isocarbonyl bridging, suggesting a monomeric $\mathrm{Mg}-\mathrm{Co}$ bonded structure. The solution IR spectrum of $\mathbf{2 3}$ in toluene also supports this, having only three $v(\mathrm{CO})$ bands (1962, $1858,1804 \mathrm{~cm}^{-1}$ ), all at comparatively high frequency. These observations are consistent with that for the structurally authenticated monomeric $\mathrm{Mg}-\mathrm{Co}$ bonded complex 14 which also exhibits three $v(\mathrm{CO})$ bands $\left(1968,1891\right.$ and $\left.1840 \mathrm{~cm}^{-1}\right)$ at high frequency only. It is notable that the bands in $\mathbf{2 3}$ are at a lower frequency than the respective bands in 14. This is consistent with the greater electron donating effect of the guanidinate vs. amidinate ligand and ultimately increased back-donation of electron density from the $\operatorname{Co}\left(\mathrm{d}_{\pi}\right)$ to $\mathrm{C}-\mathrm{O}\left(\pi^{*}\right)$ orbitals.

The $\left[\mathrm{Co}(\mathrm{CO})_{3}\left(\mathrm{PPh}_{3}\right)\right]^{-}$anion has been shown to be a viable anion for metal-metal bonding, with a range of structurally authenticated examples[14] featuring bonds to transition metals, main group metals and also electropositive metals such as in Liddle's U-Co bonded $\left(\mathrm{Ts}^{\mathrm{Xyl}}\right) \mathrm{U}\left\{\mathrm{Co}(\mathrm{CO})_{3}\left(\mathrm{PPh}_{3}\right)\right\}$ $\left(\mathrm{Ts}^{\mathrm{Xyl}}=\mathrm{HC}\left(\mathrm{SiMe}_{2} \mathrm{NXyl}\right)_{3}\right.$; Xyl = 3,5-dimethylphenyl).[30] However, our recent studies with this anion in combination with unsupported alkaline earth systems such as $\mathrm{Ca}\left\{\mathrm{Co}(\mathrm{CO})_{3}\left(\mathrm{PPh}_{3}\right)\right\}_{2}(\mathrm{THF})_{4}$ showed these complexes to have poor solubility in non-donor solvents $\left(\mathrm{Mg}\left\{\mathrm{Co}(\mathrm{CO})_{3}\left(\mathrm{PPh}_{3}\right)\right\}_{2}(\mathrm{THF})_{\mathrm{x}}\right.$ was insoluble in THF) necessitating manipulations and crystallisations from THF, giving complexes with isocarbonyl bridging between the metal centres only.[13] Therefore we were interested to see if use of a supporting, solubilising ligand could enable the isolation of a complex with the $\left[\mathrm{Co}(\mathrm{CO})_{3}\left(\mathrm{PPh}_{3}\right)\right]^{-}$anion that could be crystallised in the absence of a donor-solvent thus favouring a $\mathrm{Mg}-\mathrm{Co}$ over $\mathrm{Mg}(\mu-\mathrm{OC})$ Co interaction. Complex 21 was reacted with $\mathrm{K}\left[\mathrm{Co}(\mathrm{CO})_{3}\left(\mathrm{PPh}_{3}\right)\right](\mathrm{THF})(\mathbf{2 4}$, 
structure in the SI) in benzene to afford $\left\{\mathrm{Me}_{2} \mathrm{NC}(\mathrm{NDipp})_{2}\right\} \mathrm{Mg}\left\{\mathrm{Co}(\mathrm{CO})_{3}\left(\mathrm{PPh}_{3}\right)\right\}\left(\mathrm{OEt}_{2}\right)(\mathbf{2 5})$ as a red solid in $58 \%$ isolated yield. As with $\mathbf{2 3}$, crystals suitable for analysis by X-ray crystallography could not be obtained. NMR spectroscopic analysis confirms there is one $\mathrm{Et}_{2} \mathrm{O}$ per set of guanidinate ligand environments, consistent with that for $\mathbf{2 3}$. The solid state IR spectrum for $\mathbf{2 5}$ shows no significant low frequency $v(\mathrm{CO})$ bands. Also the solution IR spectrum for $\mathbf{2 5}$ in toluene shows only three principal $v(\mathrm{CO})$ bands $\left(2049,1976,1896 \mathrm{~cm}^{-1}\right)$, all at high frequency, consistent with a monomeric $\mathrm{Mg}-\mathrm{Co}$ bonded structure as with $\mathbf{2 3}$. The higher frequency $\mathrm{A}_{1}$ stretch for $\mathbf{2 5}$ compared to $\mathbf{2 3}$ is consistent with the lower $\sigma$-donating ability of the $\mathrm{PPh}_{3}$ compared to $\mathrm{PCy}_{3}$ group and resultant decreased $\mathrm{Co}\left(\mathrm{d}_{\pi}\right)$ to $\mathrm{C}-\mathrm{O}\left(\pi^{*}\right)$ back bonding.

\subsection{Diffusion NMR spectroscopy}

We used diffusion NMR spectroscopy to further investigate the solution phase structures of complexes 14, 15, 18, 22 and 23. The results are shown in Table 4, together with comparative reference data for $\mathbf{8}$.

Table 4. Diffusion NMR data for $\quad\left({ }^{\text {Dipp }} \mathrm{NacNac}\right) \mathrm{MgFp}(\mathrm{THF}) \quad$ (8), $\left\{\operatorname{MesC}(\mathrm{NDipp})_{2}\right\} \operatorname{Mg}\left\{\mathrm{Co}(\mathrm{CO})_{3}\left(\mathrm{PCy}_{3}\right)\right\}(\mathrm{THF}) \quad(\mathbf{1 4}), \quad\left\{\mathrm{MesC}(\mathrm{NDipp})_{2}\right\} \mathrm{MgFp}(\mathrm{THF}) \quad$ (15), $\left\{\mathrm{MesC}(\mathrm{NMes})_{2}\right\} \mathrm{Mg}\left\{\mathrm{Co}(\mathrm{CO})_{3}\left(\mathrm{PCy}_{3}\right)\right\}(\mathrm{THF}) \quad(\mathbf{1 8}), \quad\left[\left\{\mathrm{Me}_{2} \mathrm{NC}(\mathrm{NDipp})_{2}\right\} \mathrm{MgFp}\right]_{2} \quad(\mathbf{2 2}), \quad$ and $\left\{\mathrm{Me}_{2} \mathrm{NC}(\mathrm{NDipp})_{2}\right\} \mathrm{Mg}\left\{\mathrm{Co}(\mathrm{CO})_{3}\left(\mathrm{PCy}_{3}\right)\right\}\left(\mathrm{OEt}_{2}\right)(\mathbf{2 3})$.

Compound Solvent X-Ray volume NMR volume $D($ mean $) \times 10^{-10} D($ Solvent $) \times 10^{-10}$
$\left(\AA^{3}\right)^{a}$
$\left(\AA^{3}\right)^{b}$
$\left(\mathrm{m}^{2} \mathrm{~s}^{-1}\right)^{c}$
$\left(\mathrm{m}^{2} \mathrm{~s}^{-1}\right)^{c}$

\begin{tabular}{cccccc}
\hline $\mathbf{8}$ & toluene- $d_{8}$ & 698 & 519 & 7.96 & 22.02 \\
$\mathbf{1 4}$ & toluene- $d_{8}$ & 1034 & 1209 & 6.01 & 21.21 \\
$\mathbf{1 5}$ & toluene- $d_{8}$ & $936^{*}$ & 812 & 6.87 & 17.72 \\
$\mathbf{1 8}$ & toluene- $d_{8}$ & $1116^{*}$ & 1224 & 5.98 & 18.45 \\
$\mathbf{2 2}$ & toluene- $d_{8}$ & 1239 & 1139 & 6.12 & 20.19 \\
$\mathbf{2 3}$ & toluene- $d_{8}$ & $1116^{*}$ & 849 & 6.75 & 19.63 \\
$\mathbf{8}$ & THF- $d_{8}$ & 698 & 536 & 9.94 & 27.43 \\
$\mathbf{2 2}$ & THF- $d_{8}$ & 1239 & 663 & 8.84 & 26.76
\end{tabular}

${ }^{a}$ Molecular volume based on the caption formula and X-ray crystal structures measured using $1.4 \AA$ probe radius. Volumes denoted with $*$ are instead based on that expected for a monomeric structure using the $18 \AA^{3}$ rule. ${ }^{b}$ Molecular volume measured by diffusion NMR spectroscopy in toluene- $d_{8}$ or THF- $d_{8} .{ }^{c}$ Diffusion coefficient of the compound and the residual protio solvent in the sample under consideration (for comparison the diffusion coefficients for the protio solvents were $23.54 \times 10^{-10} \mathrm{~m}^{2}$ $\mathrm{s}^{-1}$ in pure toluene- $d_{8}$ and $27.0154 \times 10^{-10} \mathrm{~m}^{2} \mathrm{~s}^{-1}$ in pure THF- $d_{8}$ ). Further details are provided in the SI. 
The structure of $\mathbf{8}$ is known to be monomeric in the solid state and solution. It is also structurally similar to the amidinate and guanidinate complexes studied in this investigation making it a suitable reference molecule. Indeed the solution effective molecular volume in toluene (519 $\left.\AA^{3}\right)$ and THF (536 $\AA^{3}$ ) are similar to that expected $\left(698 \AA^{3}\right)$ based on the solid state structure. There is good agreement between the effective volume for $\mathbf{1 4}$ in the solid state $\left(1034 \AA^{3}\right)$ and solution $\left(1209 \AA^{3}\right)$ supporting this as being a monomer in both environments. It was not possible to obtain a solid state structure for 15, making the diffusion NMR measurement for this particularly insightful. The solution effective volume $\left(812 \AA^{3}\right)$ is similar to that for a monomeric structure $\left(936 \AA^{3}\right.$ ) based on that predicted using the $18 \AA^{3}$ rule.[31] As with $\mathbf{1 5}$, the solid state structure for $\mathbf{1 8}$ could not be determined but its effective monomeric volume based on the $18 \AA^{3}$ rule $\left(1116 \AA^{3}\right)$ is similar to that determined by NMR $\left(1224 \AA^{3}\right)$. Therefore based on diffusion NMR measurements the amidinate complexes 14, 15 and 18 are monomeric in solution.

Turning to the guanidinate complexes, 22 has a solution effective volume (1139 $\left.\AA^{3}\right)$ very similar to that for the dimeric solid state structure $\left(1239 \AA^{3}\right)$. The close match in effective volume suggests very little, if any, dissociation in toluene at this concentration. This is consistent with the IR spectroscopic data where a low frequency band, indicative of an isocarbonyl bridging interaction, is present in both the solid state and toluene. Diffusion NMR measurements were also made in THF- $d_{8}$. These showed a solution effective volume $\left(663 \AA^{3}\right)$ very close to half of that for the dimeric solid state structure, consistent with dissociation to monomeric units in the donor solvent environment as supported by IR spectroscopy in THF solution. Although a solid state structure could not be obtained, diffusion NMR measurements for $\mathbf{2 3}$ were carried out. There is a significant disparity (ca. 33\%) between the solution effective volume $\left(849 \AA^{3}\right)$ and that expected for a dimeric solid state structure $\left(1116 \AA^{3}\right)$ based on the $18 \AA^{3}$ rule. Whilst it may be the case that solid state volume is overestimated, the fact that the measured solution effective volume is significantly below this is strongly indicative of a monomeric structure in solution.

\section{Conclusion}

We have reported the first examples of amidinate and guanidinate supported Ae-TM bonded complexes ultimately synthesised from reduction of their corresponding carbodiimides. In order to achieve this on a suitable scale we developed an improved synthetic procedure via the corresponding thiourea. Structurally authenticated examples of Ae-TM bonded species have been achieved featuring $\mathrm{Mg}$ bonded to the $[\mathrm{Fp}]^{-}$and $\left[\mathrm{Co}(\mathrm{CO})_{3}\left(\mathrm{PCy}_{3}\right)\right]^{-}$anions. A guanidinate magnesium complex using the $\left[\mathrm{Co}(\mathrm{CO})_{3}\left(\mathrm{PPh}_{3}\right)\right]^{-}$anion was also synthesised. IR analysis is consistent with this being $\mathrm{Mg}-\mathrm{Co}$ rather than $\mathrm{Mg}(\mu-\mathrm{OC}) \mathrm{Co}$ bonded in both the solid state and solution. Crucially this introduces another anion to the limited number shown to be capable of bonding with the alkaline earth metals without suffering from the "isocarbonyl problem". Diffusion NMR spectroscopy measurements on a series of these 
complexes are consistent with them existing as monomers in toluene- $d_{8}$ with the exception of $\left[\left\{\mathrm{Me}_{2} \mathrm{NC}(\mathrm{NDipp})_{2}\right\} \mathrm{MgFp}_{2}(\mathbf{2 2})\right.$ where a dimeric structure is maintained. However, measurements in THF- $d_{8}$ were consistent with dissociation of $\mathbf{2 2}$ to monomeric units. Complex 22 was also shown to be a very rare example of a "base-free" Ae-TM complex and as having the shortest $\mathrm{Mg}-\mathrm{Fe}$ bond reported to date.

\section{Experimental}

\subsection{General}

All manipulations were carried out using standard Schlenk line or dry-box techniques under an atmosphere of argon or dinitrogen. Solvents were either degassed by sparging with dinitrogen and dried by passing through a column of the appropriate drying agent (benzene, pentane and hexane).[32] Alternatively solvents were predried over activated $4 \AA$ molecular sieves and refluxed over sodium (toluene), potassium (THF) or sodium-potassium alloy $\left(\mathrm{Et}_{2} \mathrm{O}\right)$ and distilled. Deuterated solvents were dried over sodium (toluene- $\left.d_{8}\right)$ or potassium $\left(\mathrm{C}_{6} \mathrm{D}_{6}\right.$, THF- $\left.d_{8}\right)$, distilled under reduced pressure and stored under argon in Teflon valve ampoules. NMR samples were prepared under dinitrogen in $5 \mathrm{~mm}$ Wilmad 507-PP tubes fitted with J. Young Teflon valves. ${ }^{1} \mathrm{H},{ }^{13} \mathrm{C}\left\{{ }^{1} \mathrm{H}\right\}$ and ${ }^{31} \mathrm{P}\left\{{ }^{1} \mathrm{H}\right\}$ spectra were recorded on a Bruker Ascend 400 or Varian Mercury-VX 300 at ambient temperature. ${ }^{1} \mathrm{H}$ and ${ }^{13} \mathrm{C}\left\{{ }^{1} \mathrm{H}\right\}$ spectra are referenced internally to residual protio-solvent $\left({ }^{1} \mathrm{H}\right)$ or solvent $\left({ }^{13} \mathrm{C}\right)$ resonances, and are reported relative to tetramethylsilane $(\delta=0 \mathrm{ppm}) .{ }^{31} \mathrm{P}\left\{{ }^{1} \mathrm{H}\right\}$ spectra were referenced externally to an $85 \% \mathrm{H}_{3} \mathrm{PO}_{4}$ solution. Assignments were confirmed as necessary with the use of two-dimensional ${ }^{1} \mathrm{H}-{ }^{1} \mathrm{H}$ and ${ }^{13} \mathrm{C}-{ }^{1} \mathrm{H}$ NMR correlation experiments. Diffusion NMR spectroscopic studies were performed on a Bruker Avance III 500 spectrometer (further details are contained in the SI). IR spectra were recorded on a Thermo Scientific Nicolet iS5 FTIR spectrometer and samples prepared in a dry-box as Nujol mulls between $\mathrm{NaCl}$ plates or as a solution (THF or toluene) in a $\mathrm{NaCl}$ cell. Mass spectra were recorded by the mass spectrometry service of Oxford University's Department of Chemistry. Elemental analyses were carried out by the Elemental Analysis Service at London Metropolitan University.

\subsection{Starting materials}

$\mathrm{K}[\mathrm{Fp}],[33] \quad\left[\mathrm{Co}(\mathrm{CO})_{3}\left(\mathrm{PPh}_{3}\right)\right]_{2},[34] \quad \mathrm{K}\left[\mathrm{Co}(\mathrm{CO})_{3}\left(\mathrm{PCy}_{3}\right)\right](\mathrm{THF})_{2},[13] \quad \operatorname{DippN}(\mathrm{H}) \mathrm{C}(\mathrm{S}) \mathrm{N}(\mathrm{H}) \operatorname{Dipp}$, $\operatorname{MesN}(\mathrm{H}) \mathrm{C}(\mathrm{S}) \mathrm{N}(\mathrm{H}) \mathrm{Mes}[24]$ and activated $\mathrm{Cu}[26]$ were synthesised according to published procedures. Metals and other reagents were purchased from Strem Chemicals, Sigma Aldrich or Alfa Aesar and either used as received or purified according to standard procedures.

\section{$4.3\left[\left\{\mathrm{MesC}\left(\mathrm{N}^{i} \mathrm{Pr}\right)_{2}\right\} \mathrm{Mg}(\mu-\mathrm{Br})\left(\mathrm{OEt}_{2}\right)\right]_{2}(\mathbf{9})$}

To a stirring solution of $\mathrm{MesMgBr}$ in $\mathrm{Et}_{2} \mathrm{O}(60.0 \mathrm{~mL}, 0.5 \mathrm{M}, 30.0 \mathrm{mmol})$ was added ${ }^{\mathrm{i}} \operatorname{PrNCN}{ }^{\mathrm{i}} \operatorname{Pr}(4.50$ $\mathrm{mL}, 29.0 \mathrm{mmol}$ ) dropwise. The solution was stirred for $18 \mathrm{~h}$ at room temperature to give a white 
precipitate. The solid was isolated by filtration then washed with cold $\mathrm{Et}_{2} \mathrm{O}\left(2 \mathrm{x} 20 \mathrm{~mL},-78{ }^{\circ} \mathrm{C}\right)$ before drying in vacuo to afford 9 as a white solid. Yield: $10.8 \mathrm{~g}(88 \%)$. Diffraction-quality crystals were grown from an $\mathrm{Et}_{2} \mathrm{O}$ solution at $5{ }^{\circ} \mathrm{C} .{ }^{1} \mathrm{H} \mathrm{NMR}\left(\mathrm{C}_{6} \mathrm{D}_{6}, 400.2 \mathrm{MHz}\right): \delta 6.82\left(\mathrm{~s}, 4 \mathrm{H}, \mathrm{C}_{6} \mathrm{H}_{2}\right), 3.73$ $\left(8 \mathrm{H}\right.$, quart, $\left.\left.{ }^{3} J=7.0 \mathrm{~Hz}, \mathrm{OCH}_{2}\right), 3.24\left(4 \mathrm{H}, \mathrm{sept},{ }^{3} J=5.9 \mathrm{~Hz}, \mathrm{C}^{\mathrm{HMe}}\right)_{2}\right), 2.38\left(12 \mathrm{H}, \mathrm{s}, 2,6-\mathrm{C}_{6} \mathrm{H}_{2} \underline{\mathrm{Me}}_{3}\right)$, 2.16 (6 H, s, 4- $\left.\mathrm{C}_{6} \mathrm{H}_{2} \underline{\mathrm{Me}}_{3}\right), 1.27\left(24 \mathrm{H}, \mathrm{d},{ }^{3} J=5.9 \mathrm{~Hz}, \mathrm{CHMe} \underline{\underline{e}}_{2}\right), 1.17\left(12 \mathrm{H}, \mathrm{t},{ }^{3} J=7.0 \mathrm{~Hz}, \mathrm{OCH}_{2} \underline{\mathrm{Me}}\right)$. ${ }^{13} \mathrm{C}\left\{{ }^{1} \mathrm{H}\right\}$ NMR $\left(\mathrm{C}_{6} \mathrm{D}_{6}, 100.6 \mathrm{MHz}\right): \delta 173.9\left(\mathrm{CN}_{2}\right), 136.8\left(4-\mathrm{C}_{6} \mathrm{H}_{2}\right), 134.5\left(2,6-\mathrm{C}_{6} \mathrm{H}_{2}\right), 133.6\left(1-\mathrm{C}_{6} \mathrm{H}_{2}\right)$, $128.4\left(3,5-\mathrm{C}_{6} \mathrm{H}_{2}\right), 65.5\left(\mathrm{OCH}_{2}\right), 47.2\left(\underline{\mathrm{CHMe}}_{2}\right), 26.9(\mathrm{CHMe}), 21.2\left(4-\mathrm{C}_{6} \mathrm{H}_{2} \underline{\mathrm{Me}}_{3}\right), 20.5$ (2,6$\left.\mathrm{C}_{6} \mathrm{H}_{2} \underline{\mathrm{Me}_{3}}\right), 14.5\left(\mathrm{OCH}_{2} \underline{\mathrm{Me}}\right)$. IR (NaCl plates, Nujol mull, $\left.\mathrm{cm}^{-1}\right)$ : 1355 (m), 1340 (m), 1233 (m), 1181 (m), 1166 (m), 1119 (m), 1090 (m), 1051 (m), 998 (m), 902 (w), 860 (m), 836 (w), 824 (w), 783 (m), $767(\mathrm{~m}), 693(\mathrm{w})$. EI-MS $\mathrm{m} / z=499(95 \%)\left[\left\{\mathrm{MesC}\left(\mathrm{N}^{\mathrm{i}} \operatorname{Pr}\right)_{2}\right\} \operatorname{Mg}\left\{\left(\mathrm{N}^{\mathrm{i}} \operatorname{Pr}\right)_{2} \mathrm{C}\left(\mathrm{C}_{6} \mathrm{H}_{2} \mathrm{Me}_{2}\right)\right\}\right]^{+}$. It was not possible to obtain a satisfactory elemental analysis for $\mathbf{9}$.

\section{$4.4\left\{\mathrm{MesC}\left(\mathrm{N}^{i} \mathrm{Pr}\right)_{2}\right\} \mathrm{Mg}\left\{\mathrm{Co}(\mathrm{CO})_{3}\left(\mathrm{PC} y_{3}\right)\right\}(\mathrm{THF})(11)$}

To $\left[\left\{\mathrm{MesC}\left(\mathrm{N}^{\mathrm{i}} \mathrm{Pr}\right)_{2}\right\} \mathrm{Mg}(\mu-\mathrm{Br})\left(\mathrm{OEt}_{2}\right)\right]_{2}(400 \mathrm{mg}, 0.472 \mathrm{mmol})$ and $\mathrm{K}\left[\mathrm{Co}(\mathrm{CO})_{3}\left(\mathrm{PCy}_{3}\right)\right](\mathrm{THF})_{2}(572 \mathrm{mg}$, $0.944 \mathrm{mmol})$ was added THF $(20 \mathrm{~mL})$. The brown solution was stirred for $3 \mathrm{~h}$ before removal of volatiles under reduced pressure. The dark brown solid was extracted with benzene $(3 \mathrm{x} 5 \mathrm{~mL})$ and volatiles removed under reduced pressure. The residue was washed with cold pentane $(10 \mathrm{~mL},-78$ $\left.{ }^{\circ} \mathrm{C}\right)$ and dried in vacuo to afford 11 as a grey-brown solid. Yield: $418 \mathrm{mg}(58 \%) .{ }^{1} \mathrm{H} \mathrm{NMR}_{(}\left(\mathrm{C}_{6} \mathrm{D}_{6}\right.$, 400.2 MHz): $\delta 6.79\left(2 \mathrm{H}, \mathrm{s}, \mathrm{C}_{6} \mathrm{H}_{2}\right), 4.13\left(4 \mathrm{H}, \mathrm{s}, \mathrm{OCH}_{2}\right), 3.19\left(2 \mathrm{H}, \mathrm{br} \operatorname{sept},{ }^{3} J=5.3 \mathrm{~Hz}, \mathrm{CHMe}_{2}\right), 2.43$ (6 H, s, 2,6- $\left.\mathrm{C}_{6} \mathrm{H}_{2} \underline{\mathrm{Me}}_{3}\right), 2.15$ (3 H, s, 4- $\left.\mathrm{C}_{6} \mathrm{H}_{2} \underline{\mathrm{Me}}_{3}\right), 2.04$ (3 H, m, 1- $\left.\mathrm{C}_{6} \mathrm{H}_{11}\right), 1.79$ (6 H, m, 4- $\left.\mathrm{C}_{6} \mathrm{H}_{11}\right)$, $1.64\left(12 \mathrm{H}, \mathrm{m}, 2,6-\mathrm{C}_{6} \mathrm{H}_{11}\right), 1.35\left(4 \mathrm{H}, \mathrm{s}, \mathrm{OCH}_{2} \mathrm{C}_{2}\right), 1.24\left(24 \mathrm{H}, \mathrm{d} \& \mathrm{~m}\right.$ overlapping, ${ }^{3} \mathrm{~J}=5.3 \mathrm{~Hz}$, $\left.\mathrm{CHMe}_{2} \& 3,5-\mathrm{C}_{6} \mathrm{H}_{11}\right) .{ }^{13} \mathrm{C}\left\{{ }^{1} \mathrm{H}\right\} \operatorname{NMR}\left(\mathrm{C}_{6} \mathrm{D}_{6}, 100.6 \mathrm{MHz}\right): \delta 210.2(\mathrm{~s}, \mathrm{CO}), 173.9\left(\mathrm{~s}, \mathrm{CN}_{2}\right), 136.9(\mathrm{~s}$, 4- $\left.\mathrm{C}_{6} \mathrm{H}_{2}\right), 134.6\left(\mathrm{~s}, 2,6-\mathrm{C}_{6} \mathrm{H}_{2}\right), 133.0\left(\mathrm{~s}, 1-\mathrm{C}_{6} \mathrm{H}_{2}\right), 128.5\left(\mathrm{~s}, 4-\mathrm{C}_{6} \mathrm{H}_{2}\right), 70.0\left(\mathrm{~s}, \mathrm{OCH}_{2}\right), 46.8\left(\mathrm{~s}, \underline{\mathrm{CHMe}_{2}}\right)$, $37.6\left(\mathrm{~d},{ }^{1} J=16.8 \mathrm{~Hz}, 1-\mathrm{C}_{6} \mathrm{H}_{11}\right), 30.5\left(\mathrm{~s}, 2,6-\mathrm{C}_{6} \mathrm{H}_{11}\right), 28.2\left(\mathrm{~d},{ }^{3} J=10.2 \mathrm{~Hz}, 3,5-\mathrm{C}_{6} \mathrm{H}_{11}\right), 27.0(\mathrm{~m}$, overlapping $\mathrm{CHMe}_{2}$ \& 4- $\mathrm{C}_{6} \mathrm{H}_{11}$ ), $25.3\left(\mathrm{~s}, \mathrm{OCH}_{2} \underline{\mathrm{CH}_{2}}\right.$ ), 21.2 (s, 4- $\left.\mathrm{C}_{6} \mathrm{H}_{2} \underline{\mathrm{Me}}_{3}\right), 20.6$ (s, 2,6- $\mathrm{C}_{6} \mathrm{H}_{2} \underline{\mathrm{Me}}_{3}$ ). ${ }^{31} \mathrm{P}\left\{{ }^{1} \mathrm{H}\right\}\left(\mathrm{C}_{6} \mathrm{D}_{6}, 162.0 \mathrm{MHz}\right): \delta 70.0(\mathrm{~s})$. IR (NaCl plates, Nujol mull, $\left.\mathrm{cm}^{-1}\right): 3818(\mathrm{w}), 3438(\mathrm{w}), 1963$ (m), 1922 (m), 1879 (s), 1864 (s), 1821 (m), 1756 (w), 1611 (w), 1582 (w), 1335 (m), 1240 (w), $1168(\mathrm{w}), 1143(\mathrm{w}), 1110(\mathrm{~m}), 917$ (w), 876 (w) 853 (m), 766 (w). IR (NaCl cell, toluene, v(CO),

$\mathrm{cm}^{-1}$ ): $2038(\mathrm{w}), 1969$ (m), 1904 (s), 1895 (s), 1839 (m). It was not possible to obtain a satisfactory elemental analysis for $\mathbf{1 1 .}$

\subsection{DippNCNDipp (12)}

To a stirring solution of $\operatorname{DippN}(\mathrm{H}) \mathrm{C}(\mathrm{S}) \mathrm{N}(\mathrm{H}) \operatorname{Dipp}\left(7.93 \mathrm{~g}, 20.0 \mathrm{mmol}\right.$ ) and $\mathrm{NEt}_{3}(5.58 \mathrm{~mL}, 40.0$ $\mathrm{mmol})$ in ethyl acetate $(100 \mathrm{~mL})$ was added $\mathrm{I}_{2}(5.58 \mathrm{~g}, 22.0 \mathrm{mmol})$ in portions over $30 \mathrm{~min}$. The mixture was stirred for $2 \mathrm{~h}$ at room temperature then filtered to give a brown solution. Volatiles were removed under reduced pressure to give a brown solid. The solid was extracted with pentane $(4 \mathrm{x} 50$ $\mathrm{mL})$, filtered through a silica plug and the resultant brown solution added to activated $\mathrm{Cu}(3.00 \mathrm{~g}$, 
$48.0 \mathrm{mmol}$ ). The mixture was stirred for $16 \mathrm{~h}$ at room temperature to give a black suspension. The suspension was filtered through silica to give a colourless solution. Volatiles were removed under reduced pressure and the resultant solid was dried in vacuo to afford $\mathbf{1 2}$ as a colourless crystalline solid. Yield: $4.74 \mathrm{~g}(65 \%)$. The ${ }^{1} \mathrm{H}$ NMR spectrum was consistent with that reported by Cowley et al.[24]

\section{6 [\{MesC(NDipp $\left.\left.)_{2}\right\} \mathrm{Mg}(\mu-\mathrm{Br})\left(\mathrm{OEt}_{2}\right)\right]_{2}(\mathbf{1 3})$}

To a stirring solution of $\mathrm{MesMgBr}$ in $\mathrm{Et}_{2} \mathrm{O}(43.0 \mathrm{~mL}, 0.3 \mathrm{M}, 12.9 \mathrm{mmol})$ was added a solution of DippNCNDipp (12, $4.50 \mathrm{~g}, 12.4 \mathrm{mmol})$ in $\mathrm{Et}_{2} \mathrm{O}(30 \mathrm{~mL})$ dropwise. The solution was stirred for $18 \mathrm{~h}$ to give a white precipitate. The solid was isolated by filtration and washed with cold $\mathrm{Et}_{2} \mathrm{O}(2 \times 50 \mathrm{~mL}$, $\left.-78{ }^{\circ} \mathrm{C}\right)$ before drying in vacuo to afford (13) as a white solid. Yield: $5.05 \mathrm{~g}(67 \%) .{ }^{1} \mathrm{H}$ NMR $\left(\mathrm{C}_{6} \mathrm{D}_{6}\right.$, $400.2 \mathrm{MHz}$ ): $\delta 7.02\left(12 \mathrm{H}, \mathrm{s}, \mathrm{C}_{6} \underline{\mathrm{H}}_{3}{ }^{\mathrm{i}} \mathrm{Pr}_{2}\right), 6.34\left(4 \mathrm{H}, \mathrm{s}, \mathrm{C}_{6} \underline{\mathrm{H}}_{2} \mathrm{Me}_{3}\right), 3.60$ (8 H, s, $\left.\mathrm{OCH}_{2}\right), 3.33$ (8 H, br s,

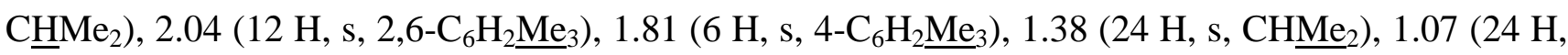
s, $\left.\mathrm{CHMe}_{2}\right), 0.91\left(12 \mathrm{H}, \mathrm{s}, \mathrm{OCH}_{2} \underline{\mathrm{Me}}\right) .{ }^{13} \mathrm{C}\left\{{ }^{1} \mathrm{H}\right\} \mathrm{NMR}\left(\mathrm{C}_{6} \mathrm{D}_{6}, 100.6 \mathrm{MHz}\right): \delta 175.0\left(\mathrm{CN}_{2}\right), 142.9$ (2- $\underline{\mathrm{C}}_{6} \mathrm{H}_{3}{ }^{\mathrm{i}} \mathrm{Pr}_{2}$ ), 141.7 (6- $\underline{\mathrm{C}}_{6} \mathrm{H}_{3}{ }^{\mathrm{i}} \mathrm{Pr}_{2}$ ), 141.2 (1- $\left.\underline{\mathrm{C}}_{6} \mathrm{H}_{3}{ }^{\mathrm{i}} \mathrm{Pr}_{2}\right), 137.9$ (4- $\left.\underline{\mathrm{C}}_{6} \mathrm{H}_{2} \mathrm{Me}_{3}\right), 137.0$ (2,6- $\left.\underline{\mathrm{C}}_{6} \mathrm{H}_{2} \mathrm{Me}_{3}\right), 130.5$ (1- $\left.\underline{\mathrm{C}}_{6} \mathrm{H}_{2} \mathrm{Me}_{3}\right), 129.6$ (3,5- $\left.\underline{\mathrm{C}}_{6} \mathrm{H}_{2} \mathrm{Me}_{3}\right), 124.1$ (4- $\left.\underline{\mathrm{C}}_{6} \mathrm{H}_{3}{ }^{\mathrm{i}} \operatorname{Pr}_{2}\right), 123.6\left(3-\underline{\mathrm{C}}_{6} \mathrm{H}_{3}{ }^{\mathrm{i}} \mathrm{Pr}_{2}\right), 123.4\left(5-\underline{\mathrm{C}}_{6} \mathrm{H}_{3}{ }^{\mathrm{i}} \mathrm{Pr}_{2}\right), 65.7$ $\left(\mathrm{OCH}_{2}\right), 28.8(\underline{\mathrm{CHMe}} 2), 27.0\left(\mathrm{CHMe}_{2}\right), 22.1\left(\mathrm{CHMe}_{2}\right), 21.6$ (2,6- $\left.\mathrm{C}_{6} \mathrm{H}_{2} \underline{\mathrm{Me}}_{3}\right), 20.6\left(4-\mathrm{C}_{6} \mathrm{H}_{2} \underline{\mathrm{Me}}_{3}\right), 13.6$ $\left(\mathrm{OCH}_{2} \underline{\mathrm{Me}}\right)$. IR ( $\mathrm{NaCl}$ plates, Nujol mull, $\left.\mathrm{cm}^{-1}\right)$ : 1437 (s), 1412 (sh), 1392 (s), 1319 (m), 1231 (w), 1189 (w), 1177 (m), 1051 (m), 996 (m), 967 (m), 949 (w), 936 (w), 889 (w), 853 (m), 834 (w), 779 (m), $762(\mathrm{~m}), 754(\mathrm{~m}), 672(\mathrm{w}), 659$ (w). Anal. found (calcd for $\mathrm{C}_{76} \mathrm{H}_{110} \mathrm{Mg}_{2} \mathrm{Br}_{2} \mathrm{~N}_{4} \mathrm{O}_{2}$ ): C, 68.92 (69.15); H, 8.52 (8.40); N, $4.28(4.24) \%$.

\section{$4.7\left\{\mathrm{MesC}(\mathrm{NDipp})_{2}\right\} \mathrm{Mg}\left\{\mathrm{Co}(\mathrm{CO})_{3}\left(\mathrm{PCy}_{3}\right)\right\}(\mathrm{THF})(\mathbf{1 4})$}

To $\left[\left\{\mathrm{MesC}(\mathrm{NDipp})_{2}\right\} \mathrm{Mg}(\mu-\mathrm{Br})\left(\mathrm{OEt}_{2}\right)\right]_{2}(\mathbf{1 3}, 500 \mathrm{mg}, 0.379 \mathrm{mmol})$ and $\mathrm{K}\left[\mathrm{Co}(\mathrm{CO})_{3}(\mathrm{PCy})\right](\mathrm{THF})_{2}$ (460 mg, $0.757 \mathrm{mmol}$ ) was added THF $(20 \mathrm{~mL}$ ). The brown solution was stirred for $18 \mathrm{~h}$ before removal of volatiles under reduced pressure. The grey solid was extracted with pentane $(3 \times 10 \mathrm{~mL})$ and volatiles removed under reduced pressure. Drying in vacuo afforded $\mathbf{1 4}$ as a grey solid. Yield: $298 \mathrm{mg}$ (39\%). ${ }^{1} \mathrm{H}$ NMR $\left(\mathrm{C}_{6} \mathrm{D}_{6}, 400.2 \mathrm{MHz}\right): \delta 7.03$ (6 H, s, 4- \& 3,5- $\left.\mathrm{C}_{6} \underline{\mathrm{H}}_{3}{ }^{\mathrm{i}} \mathrm{Pr}_{3}\right), 6.40(1 \mathrm{H}, \mathrm{s}$, 3- $\left.\mathrm{C}_{6} \underline{\mathrm{H}}_{2} \mathrm{Me}_{3}\right), 6.36\left(1 \mathrm{H}, \mathrm{s}, 5-\mathrm{C}_{6} \underline{\mathrm{H}}_{2} \mathrm{Me}_{3}\right), 4.16\left(4 \mathrm{H}, \mathrm{s}, \mathrm{OCH}_{2}\right), 3.42\left(4 \mathrm{H}\right.$, br s, $\left.\underline{\mathrm{HMe}}_{2}\right) 2.38(3 \mathrm{H}, \mathrm{s}$, 2- $\left.\mathrm{C}_{6} \mathrm{H}_{2} \underline{\mathrm{Me}}_{3}\right), 2.02\left(3 \mathrm{H}, \mathrm{m}, 1-\mathrm{C}_{6} \mathrm{H}_{11}\right), 1.95\left(3 \mathrm{H}, \mathrm{s}, 6-\mathrm{C}_{6} \mathrm{H}_{2} \underline{\mathrm{Me}}_{3}\right), 1.83\left(3 \mathrm{H}, \mathrm{s}, 4-\mathrm{C}_{6} \mathrm{H}_{2} \underline{\mathrm{Me}}_{3}\right), 1.78(6 \mathrm{H}$, m, 4- $\left.\mathrm{C}_{6} \mathrm{H}_{11}\right), 1.62\left(12 \mathrm{H}, \mathrm{m}, 2,6-\mathrm{C}_{6} \mathrm{H}_{11}\right), 1.51(12 \mathrm{H}, \mathrm{s}, \mathrm{CHMe} 2), 1.35$ (s, $\left.4 \mathrm{H}, \mathrm{OCH}_{2} \underline{\mathrm{C}}_{2}\right), 1.26(12 \mathrm{H}$, s, $\mathrm{CHMe}$ ), $1.21\left(12 \mathrm{H}, \mathrm{m}, 3,5-\mathrm{C}_{6} \mathrm{H}_{11}\right) .{ }^{13} \mathrm{C}\left\{{ }^{1} \mathrm{H}\right\}$ NMR $\left(\mathrm{C}_{6} \mathrm{D}_{6}, 100.6 \mathrm{MHz}\right): \delta 209.4$ (s, CO), 174.7 (s, $\mathrm{CN}_{2}$ ), 143.3 (s, 2- $\underline{\mathrm{C}}_{6} \mathrm{H}_{3}{ }^{\mathrm{i}} \mathrm{Pr}_{2}$ ), 142.5 (s, 6- $\underline{\mathrm{C}}_{6} \mathrm{H}_{3}{ }^{\mathrm{i}} \mathrm{Pr}_{2}$ ), 138.3 (s, 2- $\underline{\mathrm{C}}_{6} \mathrm{H}_{2} \mathrm{Me}_{3}$ ), 137.6 (s, 6- $\left.\underline{\mathrm{C}}_{6} \mathrm{H}_{2} \mathrm{Me}_{3}\right), 137.5$ (s, 4- $\underline{\mathrm{C}}_{6} \mathrm{H}_{2} \mathrm{Me}_{3}$ ), 131.0 (s, 1- $\underline{\mathrm{C}}_{6} \mathrm{H}_{2} \mathrm{Me}_{3}$ ), 130.0 (s, 3- $\underline{\mathrm{C}}_{6} \mathrm{H}_{2} \mathrm{Me}_{3}$ ), 129.3 (s, 5- $\underline{\mathrm{C}}_{6} \mathrm{H}_{2} \mathrm{Me}_{3}$ ), 127.9 (s, 1- $\underline{\mathrm{C}}_{6} \mathrm{H}_{3}{ }^{\mathrm{i}} \mathrm{Pr}_{2}$ ), 123.9 (s, 4- $\underline{\mathrm{C}}_{6} \mathrm{H}_{3}{ }^{\mathrm{i}} \mathrm{Pr}_{2}$ ), 123.7 (s, 3- $\underline{\mathrm{C}}_{6} \mathrm{H}_{3}{ }^{\mathrm{i}} \operatorname{Pr}_{2}$ ), 123.6 (s, 5- $\underline{\mathrm{C}}_{6} \mathrm{H}_{3}{ }^{\mathrm{i}} \operatorname{Pr}_{2}$ ), 71.0 (s, $\left.\mathrm{OCH}_{2}\right), 37.7$

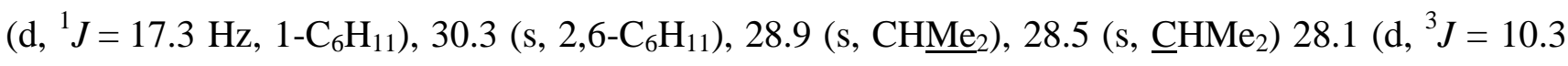
$\left.\mathrm{Hz}, 3,5-\mathrm{C}_{6} \mathrm{H}_{11}\right), 26.9$ (s, 4- $\left.\mathrm{C}_{6} \mathrm{H}_{11}\right), 25.0\left(\mathrm{OCH}_{2} \underline{\mathrm{CH}_{2}}\right), 23.8\left(2-\mathrm{C}_{6} \mathrm{H}_{2} \underline{\mathrm{Me}}_{3}\right), 22.7\left(6-\mathrm{C}_{6} \mathrm{H}_{2} \underline{\mathrm{Me}}_{3}\right), 20.6$ (4- 
$\left.\mathrm{C}_{6} \mathrm{H}_{2} \underline{\mathrm{Me}}_{3}\right) .{ }^{31} \mathrm{P}\left\{{ }^{1} \mathrm{H}\right\}\left(\mathrm{C}_{6} \mathrm{D}_{6}, 162.0 \mathrm{MHz}\right): \delta 68.6$ (s). IR (NaCl plates, Nujol mull, $\left.\mathrm{cm}^{-1}\right): 3827(\mathrm{w})$, 3747 (w), 2040 (w), 1965 (s), 1873 (s), 1612 (m), 1586 (w), 1569 (w), 1433 (s), 1413 (m), 1316 (m), 1230 (w), 1198 (w), 1174 (m), 1079 (m), 1041 (m), 963 (w), 947 (w), 935 (w), 916 (w), 875 (m), 851 (m), $777(\mathrm{~m}), 758(\mathrm{~m}), 700(\mathrm{w}), 659(\mathrm{w}), 585(\mathrm{~m}), 562(\mathrm{~m})$. IR (NaCl cell, toluene, $\left.v(\mathrm{CO}), \mathrm{cm}^{-1}\right)$ : 1968 (m), 1891 (s), 1840 (w). Anal. found (calcd for $\mathrm{C}_{59} \mathrm{H}_{86} \mathrm{CoMgN}_{2} \mathrm{O}_{4} \mathrm{P}$ ): C, 70.54 (70.75); H, 8.50 (8.66); N, $2.88(2.80) \%$.

\section{$4.8\left\{\mathrm{MesC}(\mathrm{NDipp})_{2}\right\} \mathrm{MgFp}(\mathrm{THF})(\mathbf{1 5})$}

To a stirring solution of $\left\{\mathrm{MesC}(\mathrm{NDipp})_{2}\right\} \mathrm{Mg}(\mu-\mathrm{Br})\left(\mathrm{OEt}_{2}\right)(\mathbf{1 3}, 1.00 \mathrm{~g}, 1.51 \mathrm{mmol})$ in $\mathrm{THF}(10 \mathrm{~mL})$ was added a solution of $\mathrm{K}[\mathrm{Fp}](326 \mathrm{mg}, 1.51 \mathrm{mmol})$ in THF $(10 \mathrm{~mL})$ dropwise. The reaction mixture was stirred for $2 \mathrm{~h}$ before removal of volatiles under reduced pressure. The dark brown solid was extracted with benzene $(2 \times 10 \mathrm{~mL})$ and volatiles removed under reduced pressure. The solid was triturated with pentane $(5 \mathrm{~mL})$ before removal of volatiles under reduced pressure and drying in vacuo to afford 15 as a light brown solid. Yield: $0.89 \mathrm{~g}(74 \%) .{ }^{1} \mathrm{H}$ NMR $\left(\mathrm{C}_{6} \mathrm{D}_{6}, 400.2 \mathrm{MHz}\right): \delta 7.01(6 \mathrm{H}, \mathrm{s}$, $\left.\mathrm{C}_{6} \underline{\mathrm{H}}_{3}{ }^{\mathrm{i}} \mathrm{Pr}_{2}\right), 6.36$ (2 H, s, $\left.\mathrm{C}_{6} \underline{\mathrm{H}}_{2} \mathrm{Me}_{3}\right), 4.51(5 \mathrm{H}, \mathrm{s}, \mathrm{Cp}), 4.00$ (4 H, s, OCH $), 2.96$ (2 H, br s, $\left.\mathrm{CHMe}_{2}\right)$, $2.12\left(3 \mathrm{H}, \mathrm{s}, 2-\mathrm{C}_{6} \mathrm{H}_{2} \underline{\mathrm{Me}}_{3}\right), 1.96$ (3 H, s, 6- $\left.\mathrm{C}_{6} \mathrm{H}_{2} \underline{\mathrm{Me}}_{3}\right), 1.87$ (3 H, s, 4- $\left.\mathrm{C}_{6} \mathrm{H}_{2} \underline{\mathrm{Me}}_{3}\right), 1.50$ (12 H, br s, $\left.\mathrm{CHMe}_{2}\right), 1.26\left(4 \mathrm{H}, \mathrm{s}, \mathrm{OCH}_{2} \underline{\mathrm{CH}}_{2}\right) .{ }^{13} \mathrm{C}\left\{{ }^{1} \mathrm{H}\right\} \mathrm{NMR}\left(\mathrm{C}_{6} \mathrm{D}_{6}, 100.6 \mathrm{MHz}\right): \delta 221.7(\mathrm{CO}), 173.6\left(\mathrm{CN}_{2}\right)$, $142.4 \quad\left(2,6-\underline{\mathrm{C}}_{6} \mathrm{H}_{3}{ }^{\mathrm{i}} \mathrm{Pr}_{2}\right), 137.8 \quad\left(2-\underline{\mathrm{C}}_{6} \mathrm{H}_{2} \mathrm{Me}_{3}\right), 137.7 \quad\left(4-\underline{\mathrm{C}}_{6} \mathrm{H}_{2} \mathrm{Me}_{3}\right), 137.3 \quad\left(6-\underline{\mathrm{C}}_{6} \mathrm{H}_{2} \mathrm{Me}_{3}\right), 131.2$ (1$\underline{\mathrm{C}}_{6} \mathrm{H}_{2} \mathrm{Me}_{3}$ ), 130.0 (3- $\left.\underline{\mathrm{C}}_{6} \mathrm{H}_{2} \mathrm{Me}_{3}\right), 129.8$ (5- $\left.\underline{\mathrm{C}}_{6} \mathrm{H}_{2} \mathrm{Me}_{3}\right), 128.6$ (1- $\left.\underline{\mathrm{C}}_{6} \mathrm{H}_{3}{ }^{\mathrm{i}} \mathrm{Pr}_{2}\right), 124.0$ (3- $\left.\underline{\mathrm{C}}_{6} \mathrm{H}_{3}{ }^{\mathrm{i}} \operatorname{Pr}_{2}\right), 123.8$ (4$\left.\underline{\mathrm{C}}_{6} \mathrm{H}_{3}{ }^{\mathrm{i}} \mathrm{Pr}_{2}\right), 123.6\left(5-\underline{\mathrm{C}}_{6} \mathrm{H}_{3}{ }^{\mathrm{i}} \mathrm{Pr}_{2}\right), 78.7(\mathrm{Cp}), 71.0\left(\mathrm{O}_{\underline{\mathrm{CH}}} \mathrm{CH}_{2}\right), 28.9(\underline{\mathrm{CHMe}} 2), 27.0\left(\mathrm{CHMe}_{2}\right), 25.2$ $\left(\mathrm{OCH}_{2} \underline{\mathrm{CH}}_{2}\right), 23.6\left(\mathrm{CHMe}_{2}\right), 22.8$ (2,6- $\left.\mathrm{C}_{6} \mathrm{H}_{2} \underline{\mathrm{Me}}_{3}\right), 20.6\left(4-\mathrm{C}_{6} \mathrm{H}_{2} \underline{\mathrm{Me}}_{3}\right)$. IR (NaCl plates, Nujol mull, $\mathrm{cm}^{-1}$ ): 2020 (m), 2003 (m), 1961 (sh), 1930 (s), 1866 (s), 1791 (sh), 1609 (m), 1567 (m), 1433 (s), 1412 (s), 1311 (m), 1228 (m), 1178 (m), 1078 (m), 1052 (m), 962 (w), 945 (w), 934 (w), 872 (m), 861 (m), $852(\mathrm{~m}), 815(\mathrm{~m}), 800$ (m), 779 (m), 760 (s), 698 (w), 664 (m). IR (NaCl cell, toluene, v(CO), $\left.\mathrm{cm}^{-1}\right)$ : $2017(\mathrm{~s}), 1925(\mathrm{~m})$. It was not possible to obtain a satisfactory elemental analysis for $\mathbf{1 5}$.

\subsection{MesNCNMes (16)}

To a stirring solution of $\operatorname{MesN}(\mathrm{H}) \mathrm{C}(\mathrm{S}) \mathrm{N}(\mathrm{H}) \mathrm{Mes}(12.5 \mathrm{~g}, 40.0 \mathrm{mmol})$ and $\mathrm{NEt}_{3}(11.2 \mathrm{~mL}, 80.0 \mathrm{mmol})$ in ethyl acetate $(300 \mathrm{~mL})$ was added $\mathrm{I}_{2}(10.2 \mathrm{~g}, 40.0 \mathrm{mmol})$ in portions over $30 \mathrm{~min}$. The mixture was stirred for $2 \mathrm{~h}$ at room temperature then filtered to give a brown solution. Volatiles were removed under reduced pressure to give a brown solid. The solid was extracted with pentane ( 4 x $50 \mathrm{~mL})$, filtered through a silica plug and the resultant brown solution added to activated $\mathrm{Cu}(6.10 \mathrm{~g}, 96.0$ $\mathrm{mmol}$ ). The mixture was stirred for $16 \mathrm{~h}$ at room temperature to give a black suspension. The suspension was filtered through silica to give a colourless solution. Volatiles were removed under reduced pressure and the resultant solid was dried in vасиo to afford $\mathbf{1 6}$ as a colourless crystalline solid. Yield: $6.97 \mathrm{~g}(63 \%)$. The ${ }^{1} \mathrm{H}$ NMR spectrum was consistent with that reported by Cowley et al.[24] 
To a stirring solution of $\mathrm{MesMgBr}$ in $\mathrm{Et}_{2} \mathrm{O}(43.0 \mathrm{~mL}, 0.3 \mathrm{M}, 12.9 \mathrm{mmol})$ was added a solution of MesNCNMes (16, $3.48 \mathrm{~g}, 12.5 \mathrm{mmol})$ in $\mathrm{Et}_{2} \mathrm{O}(30 \mathrm{~mL})$ dropwise. The solution was stirred for $18 \mathrm{~h}$ to give a white precipitate. The solid was isolated by filtration and washed with cold $\mathrm{Et}_{2} \mathrm{O}(2 \times 20 \mathrm{~mL}$, $-78^{\circ} \mathrm{C}$ ) before drying in vacuo to afford 17 as a white solid. Yield: $6.66 \mathrm{~g}(93 \%)$. ${ }^{1} \mathrm{H}$ NMR (THF- $d_{8}$, $400.2 \mathrm{MHz}): \delta 6.54\left(8 \mathrm{H}, \mathrm{s}, \mathrm{N}-\mathrm{C}_{6} \underline{\mathrm{H}}_{2} \mathrm{Me}_{3}\right), 6.42\left(4 \mathrm{H}, \mathrm{s}, \mathrm{C}-\mathrm{C}_{6} \underline{\mathrm{H}}_{2} \mathrm{Me}_{3}\right), 3.38\left(8 \mathrm{H}\right.$, quart, ${ }^{3} J=7.0 \mathrm{~Hz}$, $\left.\mathrm{OCH}_{2}\right), 2.18\left(24 \mathrm{H}, \mathrm{s}, \mathrm{N}-\left(2,6-\mathrm{C}_{6} \mathrm{H}_{2} \mathrm{Me}_{3}\right)\right), 2.09\left(12 \mathrm{H}, \mathrm{s}, \mathrm{C}-\left(2,6-\mathrm{C}_{6} \mathrm{H}_{2} \mathrm{Me}_{3}\right)\right), 2.06(12 \mathrm{H}, \mathrm{s}, \mathrm{N}-(4-$ $\left.\left.\mathrm{C}_{6} \mathrm{H}_{2} \underline{\mathrm{Me}}_{3}\right)\right), 2.02$ (6 H, s, C- $\left.\left(4-\mathrm{C}_{6} \mathrm{H}_{2} \underline{\mathrm{Me}}_{3}\right)\right), 1.11\left(12 \mathrm{H}, \mathrm{t},{ }^{3} J=7.0 \mathrm{~Hz}, \mathrm{OCH}_{2} \underline{\mathrm{Me}}\right) .{ }^{13} \mathrm{C}\left\{{ }^{1} \mathrm{H}\right\} \mathrm{NMR}$ $\left(\mathrm{C}_{6} \mathrm{D}_{6}, 100.6 \mathrm{MHz}\right): \delta 173.5\left(\mathrm{CN}_{2}\right), 144.9\left(\mathrm{~N}-\left(2,6-\mathrm{C}_{6} \mathrm{H}_{2}\right)\right), 137.9\left(\mathrm{C}-\left(2,6-\mathrm{C}_{6} \mathrm{H}_{2}\right)\right), 137.7\left(\mathrm{C}-\left(4-\mathrm{C}_{6} \mathrm{H}_{2}\right)\right)$, $134.7 \quad\left(\mathrm{C}-\left(1-\mathrm{C}_{6} \mathrm{H}_{2}\right)\right), \quad 132.8 \quad\left(\mathrm{~N}-\left(1-\mathrm{C}_{6} \mathrm{H}_{2}\right)\right), \quad 130.7 \quad\left(\mathrm{~N}-\left(4-\mathrm{C}_{6} \mathrm{H}_{2}\right)\right), \quad 129.5 \quad\left(\mathrm{~N}-\left(3,5-\mathrm{C}_{6} \mathrm{H}_{2}\right)\right), \quad 129.3$ $\left(\mathrm{C}-\left(3,5-\mathrm{C}_{6} \mathrm{H}_{2}\right)\right), \quad 66.5 \quad\left(\mathrm{OCH}_{2}\right), 23.3 \quad\left(\mathrm{C}-\left(2,6-\mathrm{C}_{6} \mathrm{H}_{2} \underline{\mathrm{Me}}_{3}\right)\right), 21.3 \quad\left(\mathrm{~N}-\left(2,6-\mathrm{C}_{6} \mathrm{H}_{2} \underline{\mathrm{Me}}_{3}\right)\right), 21.0 \quad(\mathrm{C}-(4-$ $\left.\left.\mathrm{C}_{6} \mathrm{H}_{2} \underline{\mathrm{Me}}_{3}\right)\right), 20.9\left(\mathrm{~N}-\left(4-\mathrm{C}_{6} \mathrm{H}_{2} \underline{\mathrm{Me}_{3}}\right)\right), 15.8\left(\mathrm{OCH}_{2} \underline{\mathrm{Me}}\right)$. IR (NaCl plates, Nujol mull, $\left.\mathrm{cm}^{-1}\right)$ : $1733(\mathrm{w})$, 1396 (s), 1205 (m), 1181 (w), 1148 (m), 1086 (m), 1048 (m), 968 (w), 936 (w), 919 (w), 909 (w), 853 (s), $834(\mathrm{w}), 787(\mathrm{~m}), 749(\mathrm{w}), 740(\mathrm{w}), 659(\mathrm{w})$. It was not possible to obtain a satisfactory elemental analysis for 17.

\section{$4.11\left\{\mathrm{MesC}(\mathrm{NMes})_{2}\right\} \mathrm{Mg}\left\{\mathrm{Co}(\mathrm{CO})_{3}\left(\mathrm{PC} y_{3}\right)\right\}(\mathrm{THF})(\mathbf{1 8})$}

To a stirring solution of $\left[\left\{\mathrm{MesC}(\mathrm{NMes})_{2}\right\} \mathrm{Mg}(\mu-\mathrm{Br})\left(\mathrm{OEt}_{2}\right)\right]_{2}(\mathbf{1 7}, 500 \mathrm{mg}, 0.434 \mathrm{mmol})$ in THF (10 $\mathrm{mL})$ was added a solution of $\mathrm{K}\left[\mathrm{Co}(\mathrm{CO})_{3}\left(\mathrm{PCy}_{3}\right)\right](\mathrm{THF})_{2}(527 \mathrm{mg}, 0.868 \mathrm{mmol})$ in $\mathrm{THF}(10 \mathrm{~mL})$ dropwise. The reaction mixture was stirred for $2 \mathrm{~h}$ before removal of volatiles under reduced pressure. The brown residue was extracted with benzene $(2 \times 10 \mathrm{~mL})$, volatiles were removed under reduced pressure and the solid dried in vacuo to afford 18 as a pale brown solid. Yield: $668 \mathrm{mg}(84 \%) .{ }^{1} \mathrm{H}$ NMR $\left(\mathrm{C}_{6} \mathrm{D}_{6}, 400.2 \mathrm{MHz}\right): \delta 6.71\left(4 \mathrm{H}, \mathrm{s}, \mathrm{N}-\left(3,5-\mathrm{C}_{6} \mathrm{H}_{2}\right)\right), 6.42\left(2 \mathrm{H}, \mathrm{s}, \mathrm{C}-\left(3,5-\mathrm{C}_{6} \mathrm{H}_{2}\right)\right), 3.98(4 \mathrm{H}, \mathrm{s}$, $\left.\mathrm{OCH}_{2}\right), 2.46\left(12 \mathrm{H}, \mathrm{s}, \mathrm{N}-\left(2,6-\mathrm{C}_{6} \mathrm{H}_{2} \underline{\mathrm{Me}}_{3}\right), 2.26\right.$ (6 H, s, C-(2,6- $\left.\mathrm{C}_{6} \mathrm{H}_{2} \underline{\mathrm{Me}_{3}}\right), 2.15\left(12 \mathrm{H}\right.$, br s, 2,6-C $\left.6 \mathrm{H}_{11}\right)$,

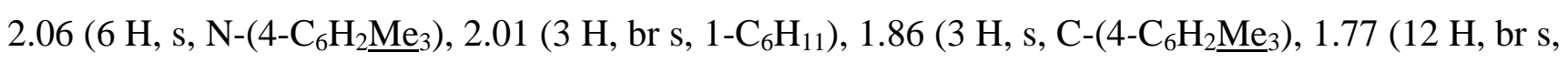
3,5- $\left.\mathrm{C}_{6} \mathrm{H}_{11}\right), 1.62\left(12 \mathrm{H}\right.$, br s, 4- $\left.\mathrm{C}_{6} \mathrm{H}_{11}\right), 1.32\left(4 \mathrm{H}\right.$, br s, $\left.\mathrm{OCH}_{2} \mathrm{CH}_{2}\right) .{ }^{13} \mathrm{C}\left\{{ }^{1} \mathrm{H}\right\} \mathrm{NMR}\left(\mathrm{C}_{6} \mathrm{D}_{6}, 100.6\right.$ $\mathrm{MHz}): \delta 211.1$ (s, CO), $172.7\left(\mathrm{CN}_{2}\right), 143.3\left(\mathrm{~s}, \mathrm{~N}-\left(2,6-\mathrm{C}_{6} \mathrm{H}_{2}\right)\right), 138.0\left(\mathrm{~s}, \mathrm{C}-\left(4-\mathrm{C}_{6} \mathrm{H}_{2}\right)\right), 137.3$ (s, C-(1$\left.\left.\mathrm{C}_{6} \mathrm{H}_{2}\right)\right), \quad 133.4 \quad\left(\mathrm{~s}, \quad \mathrm{C}-\left(2,6-\mathrm{C}_{6} \mathrm{H}_{2}\right)\right), 131.5 \quad\left(\mathrm{~s}, \quad \mathrm{~N}-\left(4-\mathrm{C}_{6} \mathrm{H}_{2}\right)\right), 130.8 \quad\left(\mathrm{~s}, \mathrm{~N}-\left(1-\mathrm{C}_{6} \mathrm{H}_{2}\right)\right), 129.9 \quad(\mathrm{~s}$, $\left.\mathrm{N}-\left(3,5-\mathrm{C}_{6} \mathrm{H}_{2}\right)\right), 129.3\left(\mathrm{~s}, \mathrm{C}-\left(3,5-\mathrm{C}_{6} \mathrm{H}_{2}\right)\right), 70.0\left(\mathrm{~s}, \mathrm{OCH}_{2}\right), 37.5\left(\mathrm{~d},{ }^{1} J=16.6 \mathrm{~Hz}, 1-\mathrm{C}_{6} \mathrm{H}_{11}\right), 30.4$ (s, 2,6$\left.\mathrm{C}_{6} \mathrm{H}_{11}\right), 28.2\left(\mathrm{~d},{ }^{3} J=10.2 \mathrm{~Hz}, 3,5-\mathrm{C}_{6} \mathrm{H}_{11}\right), 27.0\left(\mathrm{~s}, 4-\mathrm{C}_{6} \mathrm{H}_{11}\right), 25.3$ (s, OCH$\left.{ }_{2} \mathrm{CH}_{2}\right), 22.0$ (s, C-(2,6-

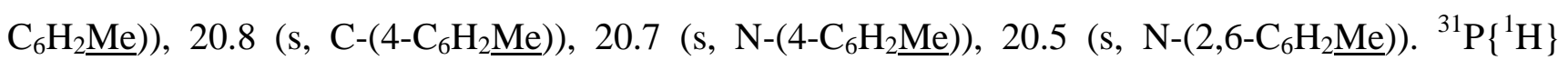
$\left(\mathrm{C}_{6} \mathrm{D}_{6}, 162.0 \mathrm{MHz}\right): \delta 70.0$ (s). IR ( $\mathrm{NaCl}$ plates, Nujol mull, $\left.\mathrm{cm}^{-1}\right): 2040(\mathrm{w}), 1964$ (sh), 1937 (s), 1885 (sh), 1865 (s), 1784 (w), 1720 (s), 1569 (w), 1425 (s), 1396 (s), 1207 (m), 1172 (w), 1148 (w), $972(\mathrm{w}), 919$ (w), 886 (m), 851 (s), 818 (w), 741 (m), 675 (w). IR (NaCl cell, toluene, $\left.v(\mathrm{CO}), \mathrm{cm}^{-1}\right)$ : 1970 (m), 1910 (m), 1890 (m), 1836 (m), 1755 (m). Anal. found (calcd for $\mathrm{C}_{53} \mathrm{H}_{73} \mathrm{CoMgN}_{2} \mathrm{O}_{4} \mathrm{P}$ ): C, 69.53 (69.39); H, 8.18 (8.13); N, 2.99 (3.05)\%. 
To a stirring solution of $\left[\left\{\mathrm{MesC}(\mathrm{NMes})_{2}\right\} \mathrm{Mg}(\mu-\mathrm{Br})\left(\mathrm{OEt}_{2}\right)\right]_{2}(\mathbf{1 7}, 300 \mathrm{mg}, 0.260 \mathrm{mmol})$ in $\mathrm{THF}(15$ $\mathrm{mL})$ was added a solution of K[Fp] $(113 \mathrm{mg}, 0.520 \mathrm{mmol})$ in THF $(10 \mathrm{~mL})$ dropwise. The reaction mixture was stirred for $3 \mathrm{~h}$ before removal of volatiles under reduced pressure. The dark brown solid was extracted with THF $(2 \times 10 \mathrm{~mL})$ and filtered before removal of volatiles under reduced pressure. The solid was triturated with pentane before removal of volatiles under reduced pressure and drying in vacuo to afford 19 as a light brown solid. Yield: $236 \mathrm{mg}(68 \%) .{ }^{1} \mathrm{H}$ NMR (THF- $\left.d_{8}, 400.2 \mathrm{MHz}\right): \delta$ $6.61\left(4 \mathrm{H}, \mathrm{s}, \mathrm{N}-\mathrm{C}_{6} \underline{\mathrm{H}}_{2} \mathrm{Me}_{3}\right), 6.52\left(2 \mathrm{H}, \mathrm{s}, \mathrm{C}-\mathrm{C}_{6} \underline{\mathrm{H}}_{2} \mathrm{Me}_{3}\right), 4.40(5 \mathrm{H}, \mathrm{s}, \mathrm{Cp}), 2.10(6 \mathrm{H}, \mathrm{s}, \mathrm{C}-(2,6-$ $\left.\left.\mathrm{C}_{6} \mathrm{H}_{2} \underline{\mathrm{Me}}_{3}\right)\right), 2.09\left(15 \mathrm{H}, \mathrm{s}, \mathrm{N}-\left(2,6-\mathrm{C}_{6} \mathrm{H}_{2} \underline{\mathrm{Me}}_{3}\right)\right.$ \& $\left.\mathrm{C}-\left(4-\mathrm{C}_{6} \mathrm{H}_{2} \underline{\mathrm{Me}}_{3}\right)\right), 1.98$ (6 H, s, N-(4-C $\left.\left.{ }_{6} \mathrm{H}_{2} \underline{\mathrm{Me}_{3}}\right)\right)$. ${ }^{13} \mathrm{C}\left\{{ }^{1} \mathrm{H}\right\}$ NMR $\left(\mathrm{C}_{6} \mathrm{D}_{6}, 100.6 \mathrm{MHz}\right): \delta 223.1(\mathrm{CO}), 172.1\left(\mathrm{CN}_{2}\right), 143.9\left(\mathrm{~N}-\left(2,6-\mathrm{C}_{6} \mathrm{H}_{2}\right)\right), 138.6$ $\left(\mathrm{C}-\left(4-\mathrm{C}_{6} \mathrm{H}_{2}\right)\right), 137.8\left(\mathrm{C}-\left(2,6-\mathrm{C}_{6} \mathrm{H}_{2}\right)\right), 134.0\left(\left(\mathrm{C}-\left(1-\mathrm{C}_{6} \mathrm{H}_{2}\right)\right)\right), 131.4\left(\mathrm{~N}-\left(1-\mathrm{C}_{6} \mathrm{H}_{2}\right)\right), 131.0\left(\mathrm{~N}-\left(4-\mathrm{C}_{6} \mathrm{H}_{2}\right)\right)$, $130.0\left(\mathrm{~N}-\left(3,5-\mathrm{C}_{6} \mathrm{H}_{2}\right)\right), 129.7\left(\mathrm{C}-\left(3,5-\mathrm{C}_{6} \mathrm{H}_{2}\right)\right), 78.8(\mathrm{Cp}), 22.2 \quad\left(\mathrm{~N}-\left(4-\mathrm{C}_{6} \mathrm{H}_{2} \mathrm{Me}_{3}\right)\right), 21.0 \quad(\mathrm{C}-(2,6-$ $\left.\left.\mathrm{C}_{6} \mathrm{H}_{2} \underline{\mathrm{Me}}_{3}\right)\right), 20.8\left(\mathrm{~N}-\left(2,6-\mathrm{C}_{6} \mathrm{H}_{2} \underline{\mathrm{Me}_{3}}\right) \& \mathrm{C}-\left(4-\mathrm{C}_{6} \mathrm{H}_{2} \underline{\mathrm{Me}_{3}}\right)\right)$. IR (NaCl plates, Nujol mull, $\left.\mathrm{cm}^{-1}\right): 2019$ (m), 1961 (sh), 1923 (s), 1858 (s), 1790 (sh), 1678 (w), 1610 (m), 1168 (w), 1147 (w), 969 (m), 955 (w), $935(\mathrm{w}), 920(\mathrm{~m}), 852(\mathrm{~s}), 676(\mathrm{~m}), 634(\mathrm{~m}), 606(\mathrm{~m}), 592(\mathrm{~m}) . \mathrm{IR}\left(\mathrm{NaCl}\right.$ cell, THF $\left.v(\mathrm{CO}), \mathrm{cm}^{-1}\right)$ : 2013 (s), 1992 (sh), 1950 (sh), 1921 (s), 1879 (sh), 1861 (s). It was not possible to obtain a satisfactory elemental analysis for 19.

\subsection{3 $\mathrm{Me}_{2} \mathrm{NC}(\mathrm{NDipp})(\mathrm{NHDipp})(\mathbf{2 0})$}

To a stirring solution of $\mathrm{LiNMe}_{2}(0.561 \mathrm{~g}, 11.0 \mathrm{mmol})$ in THF $(10 \mathrm{~mL})$ was added DippNCNDipp $(\mathbf{1 2}, 4.00 \mathrm{~g}, 11.0 \mathrm{mmol})$ over $5 \mathrm{~min}$ in THF $(10 \mathrm{~mL})$ at $-78^{\circ} \mathrm{C}$. The colourless solution was allowed to warm to room temperature then stirred for a further $2 \mathrm{~h}$ at room temperature, quenched with deionised water $(10 \mathrm{~mL})$ and extracted into $\mathrm{Et}_{2} \mathrm{O}(3 \times 10 \mathrm{~mL})$. Volatiles were removed under reduced pressure and the resultant white solid dried in vacuo to afford 20. Yield: $4.13 \mathrm{~g}$ (92\%). Diffractionquality crystals were grown from a hexane solution at room temperature. ${ }^{1} \mathrm{H}$ NMR $\left(\mathrm{C}_{6} \mathrm{D}_{6}, 400.2\right.$ $\mathrm{MHz}): \delta 7.26\left(2 \mathrm{H}\right.$, app. d, $\left.{ }^{3} J=8.0 \mathrm{~Hz}, 4-\mathrm{C}_{6} \mathrm{H}_{3}\right), 7.00\left(4 \mathrm{H}, \mathrm{d},{ }^{3} J=7.0 \mathrm{~Hz}, 3,5-\mathrm{C}_{6} \mathrm{H}_{3}\right), 5.25(1 \mathrm{H}, \mathrm{s}$, $\mathrm{NH}), 3.45$ (2 H, br m, $\left.\underline{\mathrm{HMe}}_{2}\right), 3.28$ (2 H, br m, $\left.\underline{\mathrm{HMe}}_{2}\right), 2.48\left(6 \mathrm{H}, \mathrm{s}, \mathrm{NMe}_{2}\right), 1.23\left(24 \mathrm{H}, \mathrm{d},{ }^{3} J=6.9\right.$ $\left.\mathrm{Hz}, \mathrm{CHMe} \underline{\underline{H}}_{2}\right) .{ }^{13} \mathrm{C}\left\{{ }^{1} \mathrm{H}\right\}$ NMR $\left(\mathrm{C}_{6} \mathrm{D}_{6}, 101.6 \mathrm{MHz}\right): \delta 151.3\left(\underline{\mathrm{CNMe}}_{2}\right), 145.0\left(1-\mathrm{C}_{6} \mathrm{H}_{3}\right), 140.1$ (2,6$\left.\mathrm{C}_{6} \mathrm{H}_{3}\right), 124.1\left(3,5-\mathrm{C}_{6} \mathrm{H}_{3}\right), 123.5\left(4-\mathrm{C}_{6} \mathrm{H}_{3}\right), 39.5\left(\mathrm{NMe}_{2}\right), 29.0\left(\underline{\mathrm{C}} \mathrm{HMe}_{2}\right), 28.8\left(\underline{\mathrm{CHMe}_{2}}\right), 25.0\left(\mathrm{CHMe}_{2}\right)$, $24.7\left(\mathrm{CHMe}_{2}\right), 23.4\left(\mathrm{CHMe}_{2}\right), 22.5\left(\underline{\mathrm{CHMe}}_{2}\right)$. EI-HRMS: $\mathrm{m} / \mathrm{z}$ found (calc. for $\mathrm{C}_{27} \mathrm{H}_{41} \mathrm{~N}_{3}$, $\left.\left[\mathrm{Me}_{2} \mathrm{NC}(\mathrm{NDipp})(\mathrm{NHDipp})\right]^{+}\right) 407.3303$ (407.3300). IR ( $\mathrm{NaCl}$ plates, Nujol mull, $\mathrm{cm}^{-1}$ ): 3391 (w, $v(\mathrm{NH})$ ), 1625 (s), 1260 (s), $1019(\mathrm{~m}), 761$ (w). Anal. found (calcd. for $\mathrm{C}_{27} \mathrm{H}_{41} \mathrm{~N}_{3}$ ): C, 79.46 (79.55); H, 10.30 (10.14); N, 10.25 (10.31)\%.

\section{$4.14\left\{\mathrm{Me}_{2} \mathrm{NC}(\mathrm{NDipp})_{2}\right\} \mathrm{MgI}\left(\mathrm{OEt}_{2}\right)(\mathbf{2 1})$}

To a stirring solution of $\mathrm{MeMgI}$ in $\mathrm{Et}_{2} \mathrm{O}(11.64 \mathrm{~mL}, 0.4 \mathrm{M}, 4.91 \mathrm{mmol})$ was added a solution of $\mathrm{Me}_{2} \mathrm{NC}(\mathrm{NDipp})(\mathrm{NHDipp})(\mathbf{2 0}, 2.00 \mathrm{~g}, 4.91 \mathrm{mmol})$ in $\mathrm{Et}_{2} \mathrm{O}(10 \mathrm{~mL})$ dropwise at $-20{ }^{\circ} \mathrm{C}$. The 
colourless solution was allowed to warm to room temperature and stirred for a further $2 \mathrm{~h}$. The volatiles were removed under reduced pressure to give a white solid, which was washed with hexane ( $3 \times 5 \mathrm{~mL}$ ) and dried in vacuo to afford 21 as a white solid. Yield: $2.94 \mathrm{~g}$ (95\%). Diffraction-quality crystals were grown from an $\mathrm{Et}_{2} \mathrm{O}$ solution at room temperature. ${ }^{1} \mathrm{H} \mathrm{NMR}\left(\mathrm{C}_{6} \mathrm{D}_{6}, 400.2 \mathrm{MHz}\right): \delta 7.20$ $\left(2 \mathrm{H}\right.$, br m, 4- $\left.\mathrm{C}_{6} \mathrm{H}_{3}\right), 7.14\left(4 \mathrm{H}\right.$, br m, 3,5- $\left.\mathrm{C}_{6} \mathrm{H}_{3}\right), 3.71\left(4 \mathrm{H}, \mathrm{sept},{ }^{3} J=6.8 \mathrm{~Hz}, \mathrm{CHMe}_{2}\right), 3.34(4 \mathrm{H}, \mathrm{q}$, $\left.{ }^{3} J=7.0 \mathrm{~Hz}, \mathrm{OCH}_{2}\right), 2.14\left(6 \mathrm{H}, \mathrm{s}, \mathrm{NMe}_{2}\right), 1.38\left(12 \mathrm{H}, \mathrm{d},{ }^{3} J=6.8 \mathrm{~Hz}, \mathrm{CHMe} 2\right), 1.31\left(12 \mathrm{H}, \mathrm{d},{ }^{3} J=6.8\right.$ $\left.\mathrm{Hz}, \mathrm{CHMe}_{2}\right), 0.93\left(6 \mathrm{H}, \mathrm{t},{ }^{3} J=7.0 \mathrm{~Hz}, \mathrm{OCH}_{2} \underline{\mathrm{Me}}\right) .{ }^{13} \mathrm{C}\left\{{ }^{1} \mathrm{H}\right\} \mathrm{NMR}\left(\mathrm{C}_{6} \mathrm{D}_{6}, 101.6 \mathrm{MHz}\right): \delta 167.0$ $(\underline{\mathrm{CNMe}}), 143.4\left(1-\underline{\mathrm{C}}_{6} \mathrm{H}_{3}\right), 142.9\left(2,6-\underline{\mathrm{C}}_{6} \mathrm{H}_{3}\right), 123.8\left(3,5-\underline{\mathrm{C}}_{6} \mathrm{H}_{3}\right), 123.6\left(4-\underline{\mathrm{C}}_{6} \mathrm{H}_{3}\right), 66.9\left(\mathrm{OCH}_{2}\right), 39.6$ $\left(\mathrm{NMe}_{2}\right), 27.9(\underline{\mathrm{CHMe}})$ ), $26.2(\mathrm{CHMe})$, $23.7\left(\mathrm{CHMe}_{2}\right), 14.1\left(\mathrm{OCH}_{2} \underline{\mathrm{Me}}\right)$. IR (NaCl plates, Nujol mull, $\left.\mathrm{cm}^{-1}\right): 1522$ (s), 1315 (m), 1250 (m), 1203 (m), 1100 (m), 1042 (s), 934 (w), 835 (w), 904 (m), 835 (w), 771 (s). Anal. found (calcd. for $\mathrm{C}_{31} \mathrm{H}_{50} \mathrm{IMgN} \mathrm{IM}_{3} \mathrm{O}$ ): C, 58.79 (58.92); H, 7.89 (7.98); N, 6.52 $(6.65) \%$.

\section{$4.15\left[\left\{\mathrm{Me}_{2} \mathrm{NC}(\mathrm{NDipp})_{2}\right\} \mathrm{MgFp}\right]_{2}(22)$}

To a stirring suspension of $\mathrm{K}[\mathrm{Fp}](171 \mathrm{mg}, 0.791 \mathrm{mmol})$ in $\mathrm{C}_{6} \mathrm{H}_{6}(10 \mathrm{~mL})$ was added a solution of $\left\{\mathrm{Me}_{2} \mathrm{NC}(\mathrm{NDipp})_{2}\right\} \mathrm{MgI}\left(\mathrm{Et}_{2} \mathrm{O}\right)(\mathbf{2 1}, 500 \mathrm{mg}, 0.791 \mathrm{mmol})$ in $\mathrm{C}_{6} \mathrm{H}_{6}(10 \mathrm{~mL})$ dropwise at room temperature. The mixture was stirred for $1 \mathrm{~h}$ at room temperature then filtered. Volatiles were removed from the filtrate under reduced pressure to give a red solid, which was washed with cold hexane $\left(3 \times 5 \mathrm{~mL},-78^{\circ} \mathrm{C}\right)$ and dried in vacuo to afford 22 as a yellow solid. Yield: $308 \mathrm{mg}(64 \%)$. Diffraction-quality crystals were grown from a benzene solution at $5{ }^{\circ} \mathrm{C}$. ${ }^{1} \mathrm{H}$ NMR $\left(\mathrm{C}_{6} \mathrm{D}_{6}, 400.2\right.$ MHz): $\delta 7.10\left(4 \mathrm{H}\right.$, br m, 4- $\left.\mathrm{C}_{6} \mathrm{H}_{3}\right), 6.81\left(8 \mathrm{H}\right.$, br m, 3,5- $\left.\mathrm{C}_{6} \mathrm{H}_{3}\right), 4.15(10 \mathrm{H}, \mathrm{s}, \mathrm{Cp}), 3.64(8 \mathrm{H}$, br s,

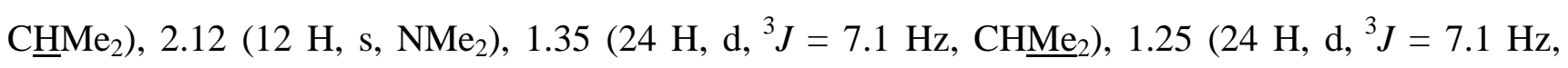

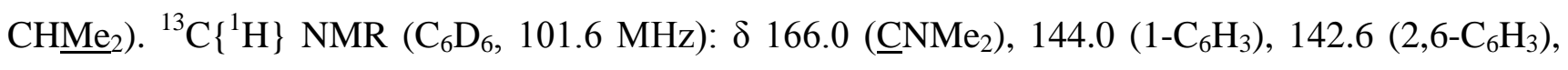
$123.8\left(3,5-\mathrm{C}_{6} \mathrm{H}_{3}\right), 123.5\left(4-\mathrm{C}_{6} \mathrm{H}_{3}\right), 80.5(\mathrm{Cp}), 39.5\left(\mathrm{NMe}_{2}\right), 28.1(\underline{\mathrm{CHMe}}), 25.7\left(\mathrm{CHMe}_{2}\right), 23.7$

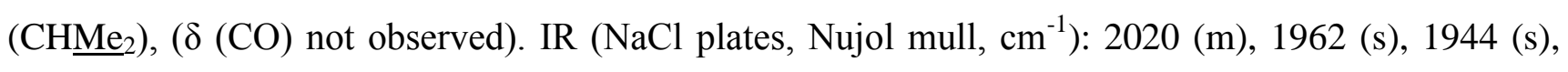
$1778(\mathrm{~s}), 1626(\mathrm{~m}), 1410(\mathrm{w}), 1018(\mathrm{~m}), 800(\mathrm{~m}), 770(\mathrm{w})$. IR (NaCl cell, toluene, $\left.v(\mathrm{CO}), \mathrm{cm}^{-1}\right): 2016$ (s), 1921 (m), 1781 (m). IR ( NaCl cell, THF, v(CO), $\mathrm{cm}^{-1}$ ): 2014 (s), 1946 (m). Anal. found (calcd. for $\mathrm{C}_{68} \mathrm{H}_{90} \mathrm{Fe}_{2} \mathrm{Mg}_{2} \mathrm{~N}_{6} \mathrm{O}_{4}$ ): C, 66.89 (67.18); H, 7.34 (7.46); N, 6.91 (6.76)\%.

\subsection{6 $\left\{\mathrm{Me}_{2} \mathrm{NC}(\mathrm{NDipp})_{2}\right\} \mathrm{Mg}\left\{\mathrm{Co}(\mathrm{CO})_{3}\left(\mathrm{PCy}_{3}\right)\right\}\left(\mathrm{OEt}_{2}\right)(\mathbf{2 3})$}

To a stirring suspension of $\mathrm{K}\left[\mathrm{Co}(\mathrm{CO})_{3}\left(\mathrm{PCy}_{3}\right)\right](\mathrm{THF})_{2}(480 \mathrm{mg}, 0.791 \mathrm{mmol})$ in $\mathrm{C}_{6} \mathrm{H}_{6}(10 \mathrm{~mL})$ was added a solution of $\left\{\mathrm{Me}_{2} \mathrm{NC}(\mathrm{NDipp})_{2}\right\} \mathrm{MgI}\left(\mathrm{Et}_{2} \mathrm{O}\right)(\mathbf{2 1}, 500 \mathrm{mg}, 0.791 \mathrm{mmol})$ in $\mathrm{C}_{6} \mathrm{H}_{6}(10 \mathrm{~mL})$ dropwise at room temperature. The mixture was stirred for $1 \mathrm{~h}$ then filtered. Volatiles were removed from the filtrate under reduced pressure and the resultant red solid (11) dried in vacuo. Yield: $410 \mathrm{mg}$ (56\%). ${ }^{1} \mathrm{H}$ NMR $\left(\mathrm{C}_{6} \mathrm{D}_{6}, 400.2 \mathrm{MHz}\right): \delta 7.20\left(4 \mathrm{H}\right.$, br m, 3,5- $\left.\mathrm{C}_{6} \mathrm{H}_{3}\right), 7.11\left(2 \mathrm{H}, \mathrm{m},{ }^{3} J=7.4 \mathrm{~Hz}, 4-\right.$ $\left.\mathrm{C}_{6} \mathrm{H}_{3}\right), 3.91\left(8 \mathrm{H}\right.$, br m, $\underline{\mathrm{HMe}}_{2}$ \& $\left.\mathrm{OCH}_{2}\right), 2.22\left(6 \mathrm{H}, \mathrm{s}, \mathrm{NMe}_{2}\right), 1.97\left(3 \mathrm{H}, \mathrm{br} \mathrm{m}, 1-\mathrm{C}_{6} \mathrm{H}_{11}\right), 1.77(6 \mathrm{H}$, br m, 4- $\left.\mathrm{C}_{6} \mathrm{H}_{11}\right), 1.56\left(12 \mathrm{H}\right.$, br m, 2,6- $\left.\mathrm{C}_{6} \mathrm{H}_{11}\right), 1.32$ (27 H, br m, $\mathrm{CHMe} 2$ \& $\left.\mathrm{OCH}_{2} \underline{\mathrm{Me}}\right), 1.21(12 \mathrm{H}$, br 
m, 3,5- $\left.\mathrm{C}_{6} \mathrm{H}_{11}\right) .{ }^{13} \mathrm{C}\left\{{ }^{1} \mathrm{H}\right\}$ NMR $\left(\mathrm{C}_{6} \mathrm{D}_{6}, 101.6 \mathrm{MHz}\right): \delta 209.4(\mathrm{~s}, \mathrm{CO}), 165.9$ (s, $\left.\mathrm{CNMe}_{2}\right), 144.0$ (s, $1-$ $\left.\mathrm{C}_{6} \mathrm{H}_{3}\right), 142.9\left(\mathrm{~s}, 2,6-\mathrm{C}_{6} \mathrm{H}_{3}\right), 123.6\left(\mathrm{~s}, 3,5-\mathrm{C}_{6} \mathrm{H}_{3}\right), 123.1$ (s, 4- $\left.\mathrm{C}_{6} \mathrm{H}_{3}\right), 70.2\left(\mathrm{~s}, \mathrm{OCH}_{2}\right), 39.9\left(\mathrm{~s}, \mathrm{NMe}_{2}\right)$, $37.6\left(\mathrm{~d},{ }^{1} J=17.1 \mathrm{~Hz},{ }^{1}-\mathrm{C}_{6} \mathrm{H}_{11}\right), 30.3\left(\mathrm{~s}, 2,6-\mathrm{C}_{6} \mathrm{H}_{11}\right), 28.1\left(\mathrm{~d},{ }^{1} J=10.6 \mathrm{~Hz}, 3,5-\mathrm{C}_{6} \mathrm{H}_{11}\right), 28.0(\mathrm{~s}$, $\underline{\mathrm{CHMe}_{2}} 26.9$ (s, 4- $\left.\mathrm{C}_{6} \mathrm{H}_{11}\right), 25.1$ (s, OCH $\left.2 \underline{\mathrm{Me}}\right), 24.0$ (s, CHMe $\left.{ }_{2}\right) .{ }^{31} \mathrm{P}\left\{{ }^{1} \mathrm{H}\right\} \mathrm{NMR}\left(\mathrm{C}_{6} \mathrm{D}_{6}, 162.0 \mathrm{MHz}\right): \delta$ 69.2 (br s). IR ( $\mathrm{NaCl}$ plates, Nujol mull, $\mathrm{cm}^{-1}$ ): 1960 (s), 1944 (s), 1879 (s), 1849 (s), 1517 (w), 769 (w). IR ( $\mathrm{NaCl}$ cell, toluene, $\left.v(\mathrm{CO}), \mathrm{cm}^{-1}\right): 1962(\mathrm{~s}), 1858(\mathrm{~m}), 1804(\mathrm{~m})$. It was not possible to obtain a satisfactory elemental analysis for $\mathbf{2 3}$.

\section{$4.17 \mathrm{~K}\left[\mathrm{Co}(\mathrm{CO})_{3}\left(\mathrm{PPh}_{3}\right)\right](\mathrm{THF})(\mathbf{2 4})$}

To a stirring $\mathrm{K}$ amalgam (121 mg, $3.08 \mathrm{mmol}$; $10 \mathrm{~mL} \mathrm{Hg}$ ) was added a red suspension of $\left[\mathrm{Co}(\mathrm{CO})_{3}\left(\mathrm{PPh}_{3}\right)\right]_{2}(500 \mathrm{mg}, 0.617 \mathrm{mmol})$ in THF $(20 \mathrm{~mL})$. The suspension was stirred over the amalgam for $16 \mathrm{~h}$ at room temperature to give a green-yellow solution, which was filtered and volatiles removed under reduced pressure. The resulting green-yellow solid was washed with pentane $(2 \times 10 \mathrm{~mL})$ and dried in vacuo to afford 24. Yield: $562 \mathrm{mg}(88 \%)$. Diffraction quality crystals were grown from a THF solution at room temperature. ${ }^{1} \mathrm{H}$ NMR (THF- $\left.d_{8}, 299.9 \mathrm{MHz}\right): \delta 7.53$ (6 H, s, 2,6$\left.\mathrm{C}_{6} \mathrm{H}_{3}\right), 7.14\left(9 \mathrm{H}, \mathrm{s}, 3,4,5-\mathrm{C}_{6} \mathrm{H}_{3}\right) .{ }^{13} \mathrm{C}\left\{{ }^{1} \mathrm{H}\right\} \mathrm{NMR}\left(\mathrm{THF}-d_{8}, 75.5 \mathrm{MHz}\right): \delta 144.0\left(\mathrm{~d},{ }^{1} J=27.1 \mathrm{~Hz}, 1-\right.$ $\left.\mathrm{C}_{6} \mathrm{H}_{3}\right), 134.3\left(\mathrm{~d},{ }^{2} J=14.0 \mathrm{~Hz}, 2,6-\mathrm{C}_{6} \mathrm{H}_{3}\right), 128.3\left(\mathrm{~s}, 4-\mathrm{C}_{6} \mathrm{H}_{3}\right), 127.9\left(\mathrm{~d},{ }^{3} J=8.7 \mathrm{~Hz}, 3,5-\mathrm{C}_{6} \mathrm{H}_{3}\right)(\delta(\mathrm{CO})$ not observed). ${ }^{31} \mathrm{P}\left\{{ }^{1} \mathrm{H}\right\}$ NMR (THF- $d_{8}, 121.4 \mathrm{MHz}$ ): $\delta 64.0$ (br s). IR (NaCl plates, Nujol mull, $\mathrm{cm}^{-1}$ ): 1932 (s), 1855 (s), 1804 (s), 1583 (w), 1435 (s), 1305 (w), 1261 (w), 1177 (w), 1084 (m), 1056 (s), 1029 (m), 914 (w), 801 (w), 750 (m), 736 (m), 697 (s), 591 (m), 575 (s). IR (NaCl cell, THF, v(CO), $\mathrm{cm}^{-1}$ ): $1925(\mathrm{~m}), 1859$ (s), 1806 (sh). Anal. found (calcd for $\mathrm{C}_{25} \mathrm{H}_{23} \mathrm{CoKO}_{4} \mathrm{P}$ ): C, 57.88 (58.14); H, $4.37(4.49) \%$.

$4.18\left\{\mathrm{Me}_{2} \mathrm{NC}(\mathrm{NDipp})_{2}\right\} \mathrm{Mg}\left\{\mathrm{Co}(\mathrm{CO})_{3}\left(\mathrm{PPh}_{3}\right)\right\}\left(\mathrm{OEt}_{2}\right)(25)$

To a stirring solution of $\mathrm{K}\left[\mathrm{Co}(\mathrm{CO})_{3}\left(\mathrm{PPh}_{3}\right)\right](\mathrm{THF})(\mathbf{2 4}, 401 \mathrm{mg}, 0.791 \mathrm{mmol})$ in $\mathrm{C}_{6} \mathrm{H}_{6}(10 \mathrm{~mL})$ was added a solution of $\left\{\mathrm{Me}_{2} \mathrm{NC}(\mathrm{NDipp})_{2}\right\} \mathrm{MgI}\left(\mathrm{OEt}_{2}\right)(\mathbf{2 1}, 500 \mathrm{mg}, 0.791 \mathrm{mmol})$ in $\mathrm{C}_{6} \mathrm{H}_{6}(10 \mathrm{~mL})$ dropwise at room temperature. The mixture was stirred for $1 \mathrm{~h}$ at room temperature then filtered. Volatiles were removed from the filtrate and the resultant red solid (25) dried in vacuo. Yield: $380 \mathrm{mg}$ (53\%). ${ }^{1} \mathrm{H}$ NMR $\left(\mathrm{C}_{6} \mathrm{D}_{6}, 400.2 \mathrm{MHz}\right): \delta 7.76\left(3 \mathrm{H}, \mathrm{t},{ }^{3} J=8.5 \mathrm{~Hz}, 2,6-\mathrm{C}_{6} \mathrm{H}_{5}\right), 7.18(2 \mathrm{H}, \mathrm{br} \mathrm{m}, 4-$ $\left.\mathrm{C}_{6} \underline{\mathrm{H}}_{3}{ }^{\mathrm{i}} \mathrm{Pr}_{2}\right), 7.08\left(4 \mathrm{H}, \mathrm{dd},{ }^{3} J=8.5,6.5 \mathrm{~Hz}, 3,5-\mathrm{C}_{6} \mathrm{H}_{5}\right), 7.06\left(2 \mathrm{H}\right.$, br m, 2,6- $\left.\mathrm{C}_{6} \mathrm{H}_{5}\right), 7.02\left(4 \mathrm{H}, \mathrm{d},{ }^{3} J=6.8\right.$ $\left.\mathrm{Hz}, 3,5-\mathrm{C}_{6} \underline{\mathrm{H}}_{3}{ }^{\mathrm{i}} \mathrm{Pr}_{2}\right), 3.83\left(8 \mathrm{H}\right.$, br m, $\left.\mathrm{CHMe}_{2} \& \mathrm{OCH}_{2}\right), 2.20\left(6 \mathrm{H}, \mathrm{s}, \mathrm{NMe}_{2}\right), 1.32(24 \mathrm{H}$, br m, $\left.\mathrm{CHMe}_{2}\right), 1.22$ (6 H, br s, OCH $\left.2 \underline{\mathrm{Me}}\right) .{ }^{13} \mathrm{C}\left\{{ }^{1} \mathrm{H}\right\} \mathrm{NMR}\left(\mathrm{C}_{6} \mathrm{D}_{6}, 101.6 \mathrm{MHz}\right): \delta 208.0$ (s, CO), 165.9 (s, $\left.\underline{\mathrm{CNMe}}_{2}\right), 144.0\left(\mathrm{~s}, 1-\underline{\mathrm{C}}_{6} \mathrm{H}_{3}{ }^{\mathrm{i}} \mathrm{Pr}_{2}\right), 142.8$ (s, 2,6- $\left.\underline{\mathrm{C}}_{6} \mathrm{H}_{3}{ }^{\mathrm{i}} \mathrm{Pr}_{2}\right), 138.5\left(\mathrm{~d},{ }^{1} J=38.0 \mathrm{~Hz}, 1-\mathrm{C}_{6} \mathrm{H}_{5}\right), 133.6\left(\mathrm{~d},{ }^{2} J=\right.$ $\left.12.0 \mathrm{~Hz}, 2,6-\mathrm{C}_{6} \mathrm{H}_{5}\right), 129.5$ (s, 4- $\left.\mathrm{C}_{6} \mathrm{H}_{5}\right), 128.1$ (3,5- $\mathrm{C}_{6} \mathrm{H}_{5}$ overlapping with solvent), 123.7 (3,5$\left.\underline{\mathrm{C}}_{6} \mathrm{H}_{3}{ }^{\mathrm{i}} \mathrm{Pr}_{2}\right), 123.2\left(4-\underline{\mathrm{C}}_{6} \mathrm{H}_{3}{ }^{\mathrm{i}} \mathrm{Pr}_{2}\right), 70.2\left(\mathrm{OCH}_{2}\right), 39.8\left(\mathrm{NMe}_{2}\right), 28.0(\underline{\mathrm{CHMe}}), 25.05\left(\mathrm{OCH}_{2} \underline{\mathrm{Me}}\right), 23.9$ $\left(\mathrm{CHMe}_{2}\right) .{ }^{31} \mathrm{P}\left\{{ }^{1} \mathrm{H}\right\}$ NMR $\left(\mathrm{C}_{6} \mathrm{D}_{6}, 162.0 \mathrm{MHz}\right): \delta 62.0$ (br s). IR (NaCl plates, Nujol mull, $\left.\mathrm{cm}^{-1}\right): 1973$ (s, v(CO)), $1887(\mathrm{~s}, \mathrm{v}(\mathrm{CO})), 1807$ (m, br v(CO)), 1520, (m), $1200(\mathrm{w}), 1016(\mathrm{w}), 865(\mathrm{~m}), 771(\mathrm{~m})$, 
$674(\mathrm{~m})$. IR ( $\mathrm{NaCl}$ cell, toluene, $\left.v(\mathrm{CO}), \mathrm{cm}^{-1}\right)$ : 2049 (s), $1976(\mathrm{~s}), 1896(\mathrm{~m})$. It was not possible to obtain a satisfactory elemental analysis for 25.

$4.19 X$-ray crystallography

Crystals were mounted on glass fibres using perfluoropolyether oil and cooled rapidly in a stream of cold $\mathrm{N}_{2}$ using an Oxford Cryosystems Cryostream unit. Diffraction data were measured using an Enraf-Nonius KappaCCD diffractometer $(\mathbf{9}, \mathbf{1 1}, \mathbf{1 7}, \mathbf{2 0}, \mathbf{2 1}, \mathbf{2 4})$ or Agilent Technologies Supernova diffractometer $(\mathbf{1 4}, \mathbf{2 2})$ using Mo- $\kappa \alpha$ or $\mathrm{Cu}-\kappa \alpha$, respectively. As appropriate, absorption and decay corrections were applied to the data and equivalent reflections merged.[35] The structures were solved using SIR92[36] or Superflip[37] and further refinements and all other crystallographic calculations were performed using the CRYSTALS program suite.[38]

\section{Acknowledgements}

We thank the Leverhulme Trust for support and Corpus Christi College, Oxford, for a Junior Research Fellowship for M. P. Blake.

\section{Appendix A. Supplementary data}

Supplementary crystallographic data for the structures of 9, 11, 14, 17, 20, 21, 22 and 24 are provided in the Supporting Information. The structures of 17, 20 and $\mathbf{2 4}$ with selected distances and angles are also provided. CCDC 1448329-1448336 contain the supplementary crystallographic data for the structurally characterised compounds. Supplementary diffusion NMR spectroscopy parameters are also provided.

\section{References}

[1] (a) S.T. Liddle, Molecular Metal-Metal Bonds: Compounds, Synthesis, Properties, Wiley, Weinheim, 2015; (b) J. Bauer, H. Braunschweig, R.D. Dewhurst, Chem. Rev. 112 (2012) 4329.

[2] I. Resa, E. Carmona, E. Gutierrez-Puebla, A. Monge, Science 305 (2004) 1136.

[3] S.P. Green, C. Jones, A. Stasch, Science 318 (2007) 1754.

[4] T. Nguyen, A.D. Sutton, M. Brynda, J.C. Fettinger, G.J. Long, P.P. Power, Science 310 (2005) 844.

[5] (a) M.P. Blake, N. Kaltsoyannis, P. Mountford, Chem. Commun. 51 (2015) 5743; (b) J. Hicks, E.J. Underhill, C.E. Kefalidis, L. Maron, C. Jones, Angew. Chem. Int. Ed. 54 (2015) 10000.

[6] D. Patel, S.T. Liddle, Rev. Inorg. Chem. 32 (2012) 1. 
[7] H. Felkin, P.J. Knowles, B. Meunier, A. Mitschler, L. Ricard, R. Weiss, J. Chem. Soc., Chem. Commun. (1974) 44.

[8] S.G. Davies, M.L.H. Green, K. Prout, A. Coda, V. Tazzoli, J. Chem. Soc., Chem. Commun. (1977) 135.

[9] J.T. Golden, T.H. Peterson, P.L. Holland, R.G. Bergman, R.A. Andersen, J. Am. Chem. Soc. 120 (1998) 223.

[10] K. Jonas, G. Koepe, C. Krüger, Angew. Chem. Int. Ed. Engl. 25 (1986) 923.

[11] H. Braunschweig, K. Gruss, K. Radacki, Angew. Chem. Int. Ed. 48 (2009) 4239.

[12] M.P. Blake, N. Kaltsoyannis, P. Mountford, J. Am. Chem. Soc. 113 (2011) 15358.

[13] M.P. Blake, N. Kaltsoyannis, P. Mountford, J. Am. Chem. Soc. 137 (2015) 12352.

[14] D.A. Fletcher, R.F. McMeeking, D. Parkin, J. Chem. Inf. Comput. Sci. 36 (1996) 746 (The UK Chemical Database Service: CSD version 5.37 updated November 2015).

[15] B. Oelkers, R. Kempe, Group 3, Lanthanide and Actinide Metal-Metal Bonds, in: S.T. Liddle (Ed.) Molecular Metal-Metal Bonds: Compounds, Synthesis, Properties, Wiley-VCH, Weinheim, 2015 , pp. 47.

[16] (a) L.H. Gade, Group 4 Metal-Metal Bonds, in: S.T. Liddle (Ed.) Molecular Metal-Metal Bonds: Compounds, Synthesis, Properties, Wiley-VCH, Weinheim, 2015, pp. 73; (b) L.H. Gade, Angew. Chem. Int. Ed. 39 (2000) 2658.

[17] H. Deng, S.G. Shore, J. Am. Chem. Soc. 113 (1991) 8538.

[18] R.S. Sternal, C.P. Brock, T.J. Marks, J. Am. Chem. Soc. 107 (1985) 8270.

[19] M.P. Blake, N. Kaltsoyannis, P. Mountford, Chem. Commun. 49 (2013) 3315.

[20] L. Bourget-Merle, M.F. Lappert, J.R. Severn, Chem. Rev. 102 (2002) 3031.

[21] (a) F.T. Edelmann, Recent Progress in the Chemistry of Metal Amidinates and Guanidinates: Syntheses, Catalysis and Materials, in: A.F. Hill, M.J. Fink (Eds.) Advances in Organometallic Chemistry Volume 61, Academic Press, San Diego, CA, 2013, pp. 55; (b) G.J. Moxey, F. Ortu, L. Goldney Sidley, H.N. Strandberg, A.J. Blake, W. Lewis, D.L. Kays, Dalton Trans. 43 (2014) 4838; 
(c) B.M. Day, W. Knowelden, M.P. Coles, Dalton Trans. 41 (2012) 10930; (d) A.R. Sadique, M.J. Heeg, C.H. Winter, Inorg. Chem. 40 (2001) 6349.

[22] D. Zhao, F.T. Lapido, J. Braddock-Wilking, L. Brammer, P. Sherwood, Organometallics 15 (1996) 1441.

[23] R.D. Theys, M.E. Dudley, M.M. Hossaun, Coord. Chem. Rev. 253 (2009) 180.

[24] M. Findlater, N.J. Hill, A.H. Cowley, Dalton Trans. (2008) 4419.

[25] A.R. Ali, H. Ghosh, B.K. Patel, Tet. Lett. 51 (2010) 1019.

[26] M. Blumer, Anal. Chem. 29 (1957) 1039.

[27] M.P. Coles, D.C. Swenson, R.F. Jordan, V.G. Young, Organometallics 16 (1997) 5183.

[28] P.J. Bailey, S. Pace, Coord. Chem. Rev. 214 (2001) 91.

[29] J. Hicks, C.E. Hoyer, B. Moubaraki, G.L. Manni, E. Carter, D.M. Murphy, K.S. Murray, L. Gagliardi, C. Jones, J. Am. Chem. Soc. 136 (2014) 5283.

[30] D. Patel, F. Moro, J. McMaster, W. Lewis, A.J. Blake, S.T. Liddle, Angew. Chem. Int. Ed. 50 (2011) 10388.

[31] (a) C.J.E. Kempster, H. Lipson, Acta Cryst. Sect. B 28 (1972) 3674; (b) C. Giacovazzo, Phasing in Crystallography: A Modern Perspective, in, Oxford University Press, Oxford, UK, 2013, pp. 50.

[32] A.B. Pangborn, M.A. Giardello, R.H. Grubbs, R.K. Rosen, F.J. Timmers, Organometallics 15 (1996) 1518.

[33] J.S. Plotkin, S.G. Shore, Inorg. Chem. 20 (1981) 284.

[34] A.R. Manning, J. Chem. Soc. A (1968) 1135.

[35] (a) Z. Otwinowski, W. Minor, Processing of X-ray Diffraction Data Collected in Oscillation Mode, Academic press, New York, 1997; (b) CrysAlisPro in, Agilent Technologies, Oxford, U.K., 2011.

[36] A. Altomare, G. Cascarano, G. Giacovazzo, A. Guagliardi, M.C. Burla, G. Polidori, M. Camalli, J. Appl. Crystallogr. 27 (1994) 435.

[37] L. Palatinus, G. Chapuis, J. Appl. Cryst. 40 (2007) 786. 
[38] P.W. Betteridge, J.R. Cooper, R.I. Cooper, K. Prout, D.J. Watkin, J. Appl. Cryst. 36 (2003) 1487. 